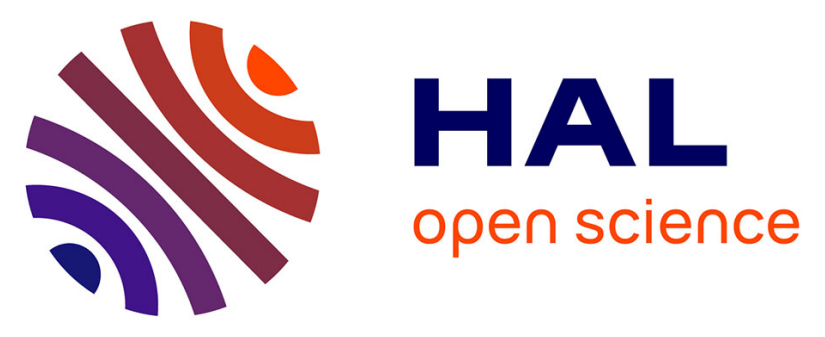

\title{
Development of a robust and efficient biogas processor for hydrogen production. Part 2: Experimental campaign
}

\author{
Y. Camacho, S. Bensaid, S. Lorentzou, N. Vlachos, G. Pantoleontos, A.
} Konstandopoulos, M. Luneau, Frédéric Meunier, N. Guilhaume, Y.

Schuurman, et al.

\section{To cite this version:}

Y. Camacho, S. Bensaid, S. Lorentzou, N. Vlachos, G. Pantoleontos, et al.. Development of a robust and efficient biogas processor for hydrogen production. Part 2: Experimental campaign. International Journal of Hydrogen Energy, 2018, 43 (1), pp.161-177. 10.1016/j.ijhydene.2017.10.177 . hal-01700694

\section{HAL Id: hal-01700694 \\ https://hal.science/hal-01700694}

Submitted on 27 Jul 2021

HAL is a multi-disciplinary open access archive for the deposit and dissemination of scientific research documents, whether they are published or not. The documents may come from teaching and research institutions in France or abroad, or from public or private research centers.
L'archive ouverte pluridisciplinaire $\mathbf{H A L}$, est destinée au dépôt et à la diffusion de documents scientifiques de niveau recherche, publiés ou non, émanant des établissements d'enseignement et de recherche français ou étrangers, des laboratoires publics ou privés. 


\title{
Development of a robust and efficient biogas processor for hydrogen production. Part 2: Experimental campaign
}

\author{
Y.S. Montenegro Camacho ${ }^{a}$, S. Bensaid ${ }^{a}$, S. Lorentzou ${ }^{b}$, N. Vlachos ${ }^{b}$, \\ G. Pantoleontos ${ }^{b}$, A. Konstandopoulos ${ }^{b}$, M. Luneau ${ }^{c}$, F.C. Meunier ${ }^{c}$, \\ N. Guilhaume ${ }^{c}$, Y. Schuurman ${ }^{c}$, E. Werzner ${ }^{d}$, A. Herrmann ${ }^{d}$, F. Rau ${ }^{d}$, \\ H. Krause ${ }^{d}$, E. Rezaei $^{e}$, A. Ortona $^{e}$, S. Gianella ${ }^{f}$, A. Khinsky $^{g}$, \\ M. Antonini ${ }^{h}$, L. Marchisio ${ }^{h}$, F. Vilardo ${ }^{h}$, D. Trimis ${ }^{i}$, D. Fino ${ }^{a, *}$ \\ a Politecnico di Torino, Department of Applied Science and Technology, Corso Duca degli Abruzzi 24, Torino 10129, \\ Italy \\ ${ }^{\mathrm{b}}$ Aerosol \& Particle Technology Laboratory (CERTH-CPERI), 6 th km Charilaou - Thermis, PO BOX 60361,57001 \\ Thermi, Thessaloniki, Greece \\ ' Université de Lyon, Institut de Recherches sur la Catalyse et l'Environnement de Lyon, IRCELYON UMR5256 CNRS, \\ 2 Avenue Albert Einstein, F-69626 Villeurbanne Cedex, France \\ d Institute of Thermal Engineering, Technische Universität Bergakademie Freiberg, Gustav - Zeuner - Straße 7, \\ 09596 Freiberg, Sachsen, Germany \\ e ICIMSI, SUPSI, Galleria 2, CH-6928 Manno, Switzerland \\ ${ }^{\mathrm{f}}$ Erbicol SA, Viale Pereda 21, CH6228, Balerna, Switzerland \\ ${ }^{g}$ Amiagus, Savanoriu str. 290, LT-49473 Kaunas, Lithuania \\ ${ }^{\mathrm{h}}$ Hysytech Srl, Strada del Drosso, 33/18, Torino, Italy \\ ${ }^{\mathrm{i}}$ Karlsruhe Institute of Technology, Engler-Bunte-Institute, Engler-Bunte-Ring 7, 76131 Karlsruhe, Germany
}

In this study, a robust and efficient decentralized fuel processor based on the direct autothermal reforming (ATR) of biogas with a nominal production rate of $50 \mathrm{Nm}^{3} / \mathrm{h}$ of hydrogen and a plant efficiency of about $65 \%$ was developed and tested. The ATR unit is composed of a structured catalyst support for the biogas reforming close coupled to a catalytic wall-flow filter to retain eventual soot particles.

The performance of the conventional random foam and homogeneous lattice supports structures for the production of hydrogen from the ATR reaction was investigated. 15-0.05 wt\%-Ni-Rh/ $\mathrm{MgAl}_{2} \mathrm{O}_{4}$-SiSiC structured catalyst and $\mathrm{LiFeO}_{2}$-SiC monolith were selected for the conversion of biogas to hydrogen and for the syngas post-treatment process, respectively. For all the experiments, a model synthetic biogas was used and the catalytic activities were evaluated in three different experimental facilities: lab bench, pilot test rig and demonstration plant. High methane conversions (>95\%) and hydrogen yields $(>1.8)$ reached in the lab bench were also achieved in the pilot and demonstration plant operating at different GHSV.

Results of duration test using a foam coupled to the filter has demonstrated that the pre-commercial processor is reliable while offering a satisfactory reproducibility and

\footnotetext{
* Corresponding author.

E-mail address: debora.fino@polito.it (D. Fino).
} 
negligible pressure drop. A thermodynamic equilibrium and a cold gas efficiency of $90 \%$ were reached for an inlet temperature of $500{ }^{\circ} \mathrm{C}, \mathrm{O} / \mathrm{C}: 1.1$ and S/C: 2.0 , as predicted with the Aspen simulation.

\section{Introduction}

Hydrogen is one of the most promising fuel for energy and transport applications, providing solutions to environmental and economic challenges [1-3]. Energy carriers are used to move, store and deliver energy in a form that can be easily used. Hydrogen is a clean energy carrier similar to electricity $[4,5]$. Furthermore, hydrogen is a flexible and scalable energy vector which can be used for short- and longer-term energy storage. Moreover, hydrogen has high energy capacity, with the largest amount of energy per mass unit than any other know substance $(121,000 \mathrm{~kJ} / \mathrm{kg})$ [6]. Green hydrogen can be used in fuel cells to produce power and heat cleanly and efficiently in a wide range of transportation and power generation in stationary and portable applications [6].

Nowadays, the most cost-effective way to produce hydrogen is from the steam reforming (SR) of fossil resources, such as natural gas and coal [6-10]. Environmental pollution, global warming, and the limited supply are the main disadvantage of fossil fuels [11,12]. Then, due to environmental concerns, hydrogen production from renewable sources such as solar, wind, biomass and biogas are needed [3].

Hydrogen production from biogas is a highly promising energy carrier in the sustainable energetic scenario of reduced greenhouse gas emissions $[6,8,10]$. Biogas is produced from the anaerobic digestion of organic residues from several origins, typically, it is essentially composed of methane $\left(\mathrm{CH}_{4}\right.$, around $55-70 \%)$ and carbon dioxide $\left(\mathrm{CO}_{2}\right.$, around $\left.30-45 \%\right)$, but also contains trace gases of ammonia $\left(\mathrm{NH}_{3}\right)$, hydrogen $\left(\mathrm{H}_{2}\right)$, nitrogen $\left(\mathrm{N}_{2}\right)$, vapor water $\left(\mathrm{H}_{2} \mathrm{O}\right)$, hydrogen sulfide $\left(\mathrm{H}_{2} \mathrm{~S}\right)$ and oxygen $\left(\mathrm{O}_{2}\right)$ $[6,13]$. Biogas can be directly used as a combustible; however, the combustion process of biogas to generate heat has a low efficiency, because the humidity and $\mathrm{CO}_{2}$ content decrease the calorific value of the fuel [14-18]. A promising possibility is to produce $\mathrm{H}_{2}$ by reforming of biogas, which can be then supplied to fuel cell as proposed in the present work. In a catalytic reforming process, the presence of $\mathrm{CO}_{2}$ and humidity in the biogas are advantageous for converting biogas into $\mathrm{H}_{2}$ via dry and steam reforming reactions.

Hydrogen can be produced from biogas reforming through four different technologies, dry reforming (DR), steam reforming (SR), catalytic partial oxidation (CPOX), and auto thermal reforming (ATR).

DR of methane is an endothermic reaction (R.1) and should be conducted at high temperatures $\left(800-900{ }^{\circ} \mathrm{C}\right)$ to produce syngas $\left(\mathrm{CO}\right.$ and $\mathrm{H}_{2}$ ) yielding a $\mathrm{H}_{2} / \mathrm{CO}$ ratio close to one. This value is considered to be the most appropriate for Fischer-Tropsch and other synthesis reactions for the production of liquid hydrocarbons [19].

$$
\mathrm{CH}_{4}+\mathrm{CO}_{2} \leftrightarrow 2 \mathrm{CO}+2 \mathrm{H}_{2} \quad \Delta \mathrm{H}_{298}^{\circ}=+247 \mathrm{~kJ} / \mathrm{mol}
$$

According to the literature there are parallel reactions such as the reverse water-gas shift reaction (R.2 reverse) and carbon forming reactions, Boudouard reaction (decomposition of CO) (R.3) and decomposition of $\mathrm{CH}_{4}$ (R.4), which modify the equilibrium conversion of $\mathrm{CO}_{2}$ and $\mathrm{CH}_{4}$. So, catalysts are useful in order to decrease the activation energy of the DR reaction and increases the selectivity to $\mathrm{H}_{2}$ and $\mathrm{CO}$ while decreases the selectivity to carbon formation.

$$
\begin{aligned}
& \mathrm{H}_{2} \mathrm{O}+\mathrm{CO} \leftrightarrow \mathrm{CO}_{2}+\mathrm{H}_{2} \quad \Delta \mathrm{H}_{298}^{\circ}=-41.2 \mathrm{~kJ} / \mathrm{mol} \\
& 2 \mathrm{CO} \leftrightarrow \mathrm{C}+\mathrm{CO}_{2} \quad \Delta \mathrm{H}_{298}^{\circ}=-172 \mathrm{~kJ} / \mathrm{mol} \\
& \mathrm{CH}_{4} \leftrightarrow \mathrm{C}+2 \mathrm{H}_{2} \quad \Delta \mathrm{H}_{298}^{\circ}=74.9 \mathrm{~kJ} / \mathrm{mol}
\end{aligned}
$$

In the CPOX process, methane is partially oxidized over a catalyst bed to produces syngas with $\mathrm{H}_{2}$ to $\mathrm{CO}$ ratio close 2 , at atmospheric pressure. The reaction (R.5) is moderately exothermic and requiring temperatures between 700 and $900{ }^{\circ} \mathrm{C}$ to ensure complete conversion and to reduce soot formation [6]. As agreement in literature, the highly exothermic combustion of methane also take a place at the beginning of the catalyst bed, which results in high reaction temperature increase, which in turn can lead coke formation [13,20].

$\mathrm{CH}_{4}+\frac{1}{2} \quad \mathrm{O}_{2} \rightarrow \mathrm{CO}+2 \mathrm{H}_{2} \quad \Delta \mathrm{H}^{\circ}{ }_{298}=-36 \mathrm{~kJ} / \mathrm{mol}$

SR of methane as aforementioned is currently the most widespread and at the same time least expensive process for hydrogen production. SR is also an endothermic reaction (R.6), where the methane reacts with water vapor to produce $\mathrm{H}_{2}$ and $\mathrm{CO}$ in a range of temperature between $650^{\circ} \mathrm{C}$ and $850^{\circ} \mathrm{C}$.

$\mathrm{CH}_{4}+\mathrm{H}_{2} \mathrm{O} \leftrightarrow \mathrm{CO}+3 \mathrm{H}_{2} \quad \Delta \mathrm{H}_{298}^{\circ}=+206.2 \mathrm{~kJ} / \mathrm{mol}$

$\mathrm{H}_{2} / \mathrm{CO}$ ratio produced in SR is equal to three and commonly steam is introduced in excess in order to shift the water-gas shift equilibrium (R.2) which enables towards the production of an additional amount of $\mathrm{H}_{2}$ and less $\mathrm{CO}$ production at the reactor outlet $[6,7]$.

A syngas production method in large-scale with higher energy efficiency than steam reforming technology is required. Since the endothermic heat due to reforming reactions is supplied from the reactor outside, the reaction rate is limited by the heat transfer [21]. ATR process has recently been the preferred technology for large scale Fischer-Tropsch-plants $[21,22]$.

In the ATR process, the endothermic (SR) and exothermic (CPOX) reactions are coupled. The peculiar feature of ATR lies in the fact that heat is directly provided within the reactor, through partial oxidation of the biogas. This reduces the need of heat exchangers, and increases the flexibility of the plant [23]. 
The ATR process also occurs in the presence of $\mathrm{CO}_{2}$ as shown by equation (Eq. (7)):

$$
\mathrm{CH}_{4}+\frac{1}{2} \mathrm{xO}_{2}+\mathrm{yCO}_{2}+(1-\mathrm{x}-\mathrm{y}) \mathrm{H}_{2} \mathrm{O} \leftrightarrow(\mathrm{y}+1) \mathrm{CO}+(3-\mathrm{x}-\mathrm{y}) \mathrm{H}_{2}
$$

In reforming process, nickel $(\mathrm{Ni})$ and the noble metals $(\mathrm{Ru}$, $\mathrm{Rh}, \mathrm{Pd}, \mathrm{Ir}, \mathrm{Pt}$ ) based catalysts have been widely investigated [24-26]. Noble metal catalysts exhibit higher activity and stability combining with better resistance to the problem of carbon deposition, and deactivation compared to $\mathrm{Ni}$ catalyst [27-29]. However, they are very expensive and of low availability to have a major impact on the total reforming catalyst market $[12,26,30,31]$. For these reasons, many studies have focused on the improvement of "low cost" nickel catalysts, to achieve greater catalytic activity and stability, through the modification of the structure and morphological properties [12]. Consequently, it has been demonstrated that the methane conversion, catalytic stability and resistance to deactivation improvement markedly with the addition of small amount of noble metals to Ni-based catalyst, also for ATR of biogas to produce hydrogen [20,32-34]. According to Wu and Chou the synergy of the bimetallic catalysts can increase the conversion of $\mathrm{CH}_{4}$ and the yield of $\mathrm{H}_{2}$ [35]. The promoting effect of noble metals on the reduction of Ni species can be interpreted by the hydrogen spillover phenomenon. On the metallic surface, $\mathrm{H}_{2}$ molecules dissociate to hydrogen species, which are diffused to different species via the support surface $[21,36,37]$.

Furthermore, the support also has an influence on the catalytic activity due to chemical effect or interaction between the active phase and the support phase [10]. The use of promoters and catalyst supports with basic properties can enhance the resistance of the catalyst to carbon formation $[10,30,38,39]$. Most common supports are $\alpha$ - and $\gamma-\mathrm{Al}_{2} \mathrm{O}_{3}, \mathrm{MgO}$, $\mathrm{MgAl}_{2} \mathrm{O}_{4}, \mathrm{TiO}_{2}, \mathrm{ZrO}_{2}$ and $\mathrm{CeO}_{2}$ [40]. Alumina is commonly used as a support for the Ni catalyst [10]. This is due to the fact that the alumina support increases the overall basicity of the supported $\mathrm{Ni}$ catalyst and there is a stronger metal-support interaction between the Ni and alumina support [38]. However, during the reforming process, the inactive nickel spinel phase $\left(\mathrm{NiAl}_{2} \mathrm{O}_{4}\right)$ can be formed accelerating the deactivation $[10,20,33]$. Furthermore, several studies reported that, the incorporation of basic metals such as $\mathrm{Mg}$ and $\mathrm{Ca}$ into $\mathrm{Al}_{2} \mathrm{O}_{3}$ based catalysts improve both stability and activity $[10,20,41,42]$. However, until now, it is still in challenge to find a new catalyst support and develop a new Ni-based catalyst with high selectivity for carbon free operation, that not only enhance the mass and heat transfer, but also be resistant to metal sintering.

On the other hand, the use of structured catalysts characterized by highly thermal conductive materials can improve the heat transfer along the catalytic bed, providing a better performance. Recently, silicon carbide (SiC) as catalyst support has been applied for various catalytic reactions [43-48]. $\mathrm{SiC}$ is a suitable support, it has excellent heat conductivity, strong mechanical hardness, high resistance to oxidation and extreme chemical inertness to acid and base [47]. Moreover, the catalyst supported on the $\mathrm{Al}_{2} \mathrm{O}_{3}$-coated $\mathrm{SiC}$ foam monolith showed a more homogeneous bed temperature distribution compared with a conventional spinel supported Ni-based catalyst [46].

Recently, Wei and coworkers used a monolithic $\mathrm{Ni}-\mathrm{Al}_{2} \mathrm{O}_{3}-\mathrm{SiC}$ catalyst for the combined reaction of DR-POX to produce syngas and showed excellent catalytic performances and longer life time compared to a reference catalyst (Ni-SiC) [47]. Further, Ricca et al. in a study has confirmed that the use of structured catalysts leads to a clear intensification of the reforming process; the tests have shown that the use of structured catalysts allows a flattening of the radial thermal profile. This effect leads to a higher performance that provides greater methane conversion and hydrogen yield. Moreover, they have shown that the SiC carriers, in "wall-flow" configuration showed a higher catalytic activity than other monoliths (cordierite honeycomb monolith and SiC-monolith "flow through") [48].

It has been pointed out that one problem in biogas reforming is carbon deposition on the catalyst surface, which causes the catalyst deactivation, plugging of the reactor, and breakdown of the catalyst. The carbon that could be formed during the ATR of biogas can be filter downstream in a soot trap and it gasify with the gases obtained from the ATR unit. The syngas produced by ATR reforming is constituted by $\mathrm{CO}_{2}$, $\mathrm{CO}, \mathrm{H}_{2}$ and steam. The possibility to gasify soot in this specific environment can be reached according to the reaction R.8 and the reverse R.3, which are known as the steam gasification and the reverse Boudouard reaction, respectively [49]:

$$
\mathrm{C}+\mathrm{H}_{2} \mathrm{O} \leftrightarrow \mathrm{CO}+\mathrm{H}_{2} \quad \Delta \mathrm{H}_{298}^{\circ}=131.4 \mathrm{~kJ} / \mathrm{mol}
$$

Filters are efficient means for the removal of particulate matter from gaseous streams that find applications in several different processes. A characteristic example is the case of diesel exhaust emission control where Diesel Particulate Filters (DPFs), based mainly on wall-flow honeycomb monolithic structures, which are used for the removal of soot particles and are considered an essential component of the exhaust of diesel engines [49-53].

Therefore, from the chemical and engineering point of view, optimization of the catalyst should extend the scale of operation of the biogas reforming. In particular, the structured high conductivity catalyst should allow obtaining appreciable yields for a high reagent rate and a relatively low temperature for long periods, reducing the use of noble metal based formulations [48]. In fact, this is one of the main challenges facing this study.

In this research, a robust and efficient decentralized (TRL 5 pre-commercial) fuel processor for the production of $50 \mathrm{Nm}^{3} / \mathrm{h}$ of hydrogen, based on the direct ATR of biogas has been developed and tested. The overall originality of this work is the use of structured catalyst for the ATR reaction, which is based on high thermal conductivity cellular materials to disperse the heat axially in the reactor. Moreover, a key innovation is also the adaptation of a wall-flow filter close coupled to the ATR unit, which could entail effective filtration and conversion of any soot like particles eventually generated by hetero-homogeneous reactions in the inlet part of the ATR reactor during normal operation or due to the decomposition of traces of incomplete reforming products. 
In the present study, the catalytic performance of random foams and homogeneous lattice supports designed in our previous work [54], has been studied, and the results obtained have been validated. The supports were manufactured by replica of 3D-printed structures followed by Silicon infiltration. SiSiC structures were coated with the same amount of Ni-based catalysts doped with noble metals while the wallflow filter was coated with $\mathrm{LiFeO}_{2}$ catalyst. In order to optimize operating conditions, ensure the reliability and provide a satisfactory reproducibility of the pre-commercial processor, both catalyst supports were tested under similar conditions in three different scale levels of experimental facilities: lab bench, pilot test rig and demonstration plant.

\section{Experimental}

In the first part of this research work devoted to concept modelling and simulation, the overall process to produce hydrogen from the ATR of biogas was explained [54]. In general, the process comprises three steps. In the first stage, the section of compression, preheating and mixing (educt processing) is carried out. The biogas reforming takes place in the second step, in which the ATR unit is closely coupled to the wall flow filter. The last section consists of the gas purification but, as shown in Fig. 1, it was not performed inside this experimental part, due to the huge availability of equipment for the syngas purification. However, it was considered for process optimization and fuel processor efficiency calculations. In place of the syngas purification, a flare was located after the soot trap to burn the syngas produced in the process, as shown in Fig. 1.
This work includes three scale levels of experimental facilities as illustrated in Fig. 2. The experimental configurations used to test the catalytic activity of the synthesized catalysts to be coated onto the respective supports (powder scale) are in the upper part of the Figure. In the upper left hand side is the one used for the biogas ATR and in the upper right hand side, the one for gasification of soot in a syngas atmosphere. In the middle of the figure, the pilot plant is depicted in which the structural support and the wall flow monolith were evaluated in realistic conditions to see specially the interaction or penalty in terms of pressure drop of whole coupled system. Methane conversion and hydrogen yield were also evaluated in a long-term test. By last, in the bottom of the Fig. 2 there is the demonstration plant for the production of $50 \mathrm{Nm}^{3} / \mathrm{h}$ of hydrogen.

Three levels of scale up were investigated due the fact that the flexibility design in a demo plant is still a very critical factor because it is not known what is to come. Unlike, a pilot plant is intended to verify only certain process operations, while a demonstration plant portrays a fuller picture of what lies ahead in a commercial plant.

\section{Catalyst for the autothermal reforming of biogas}

The catalyst for the ATR of biogas must guarantee important features such as less prone to coking and easier adaptability to the change of biogas composition.

\section{Catalyst preparation and characterization}

Different catalysts were synthesized and tested along with some commercial catalysts in order to select the most appropriate one for the ATR biogas reformer. Nickel supported

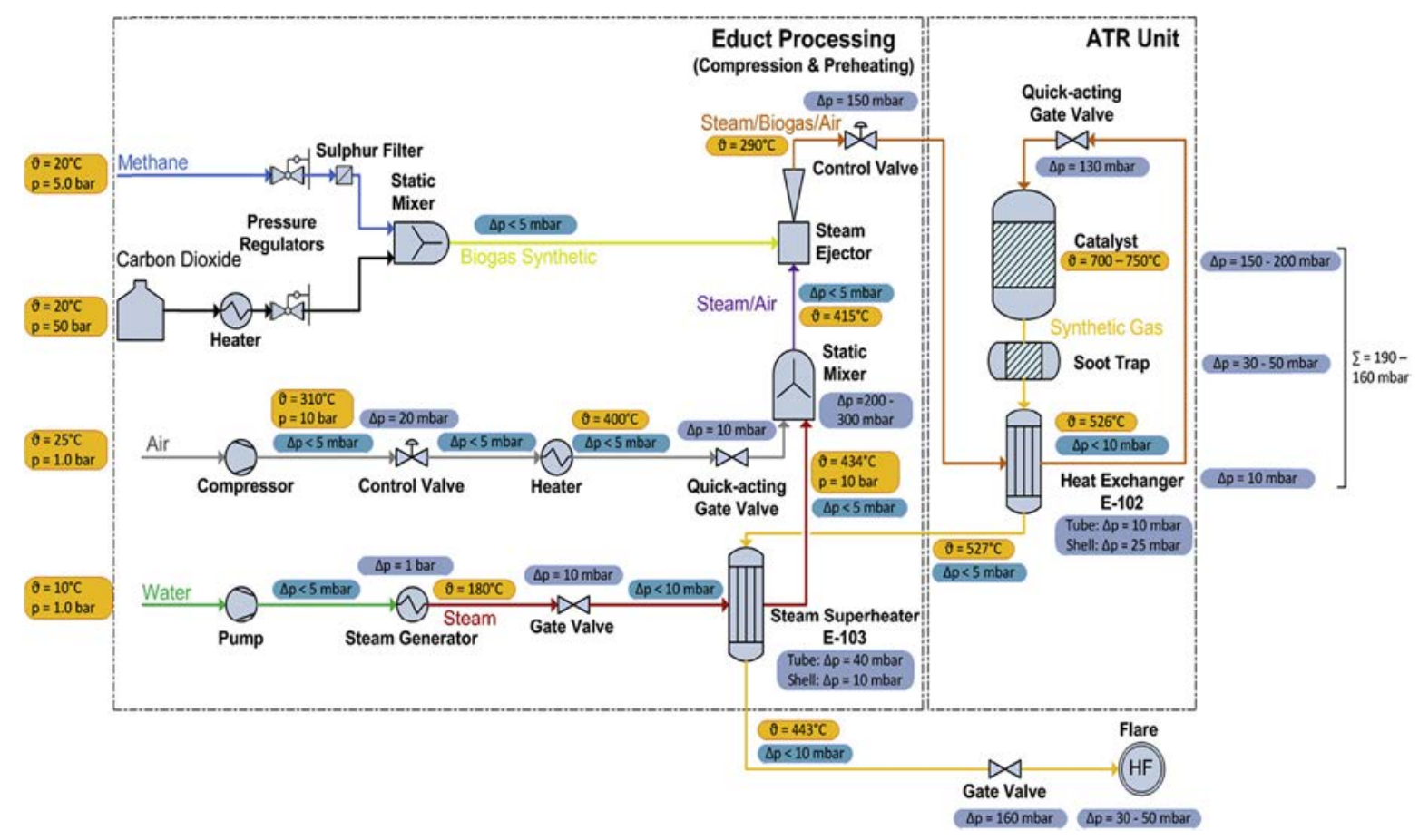

Fig. 1 - Block flow diagram of hydrogen production from biogas via ATR process. 


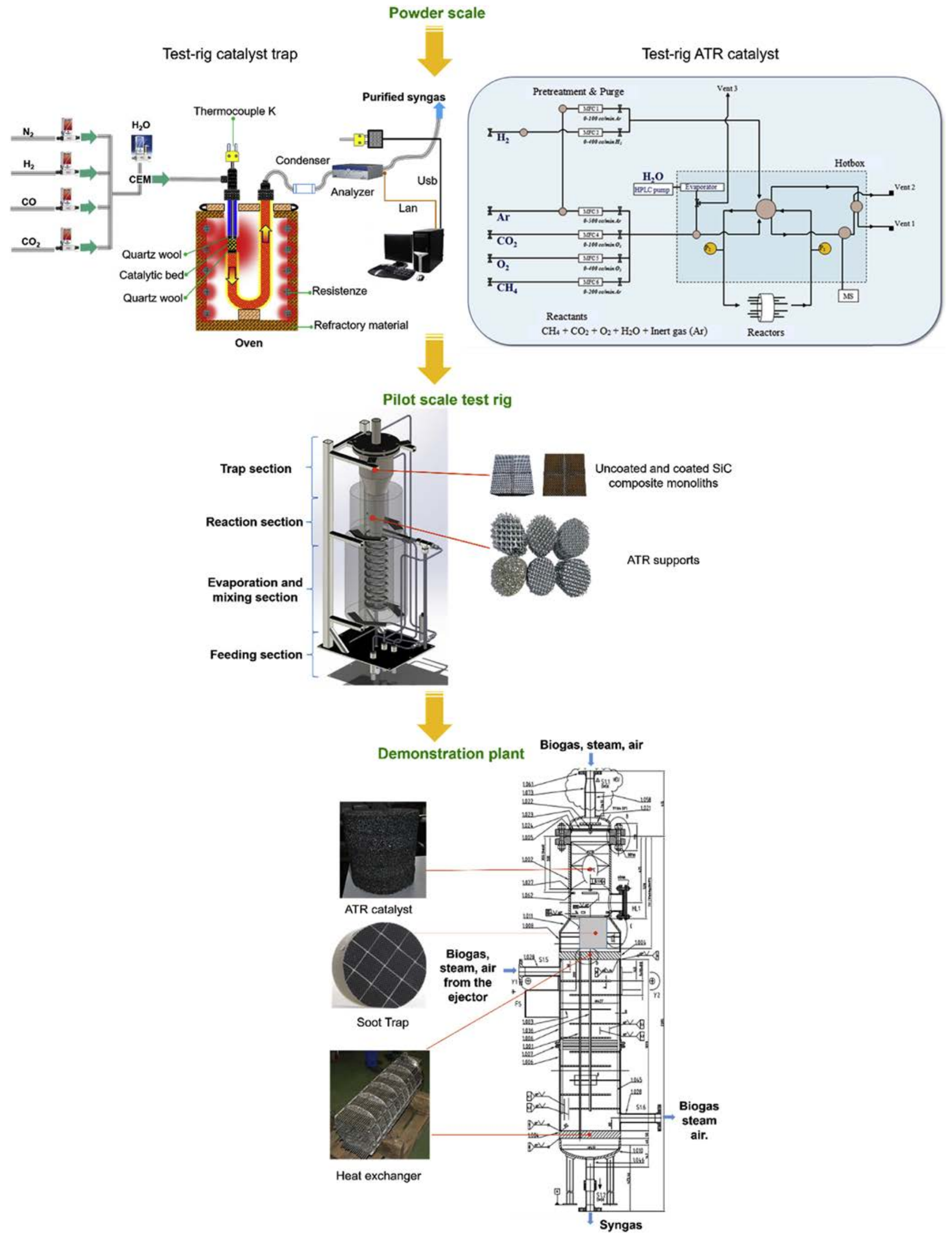

Fig. 2 - Scale levels of the experimental application for hydrogen production from biogas. 
on mixed oxides, perovskites and spinels were synthesized and tested for long-term stability. The most stable catalysts were then studied in more detail and further optimized. An additional constrain was to minimize the amount of platinum group metals in the catalyst formulation. Details on the catalyst preparation and characterization can be found in Ref. [20].

\section{Catalytic activity tests}

The catalysts were tested in a six parallel-flow reactor technology running simultaneously six different catalysts with a feed of $42 \% \mathrm{H}_{2} \mathrm{O}, 14 \% \mathrm{CH}_{4}, 9 \% \mathrm{CO}_{2}, 7 \% \mathrm{O}_{2}$ in argon (Fig. 2 (topright)) [20]. The catalysts were reduced in situ with $\mathrm{a}_{2}$ argon mixture (4:1 vol:vol) for $3 \mathrm{~h}$, at $700^{\circ} \mathrm{C}$. Tests were performed in quartz reactors with a length of $180 \mathrm{~mm}$ and an inner diameter of $4 \mathrm{~mm}$ at $700{ }^{\circ} \mathrm{C}$ (oven set point) and 1.6 bar. Catalyst beds were composed of $20 \mathrm{mg}$ of prepared catalyst diluted with quartz powder to assure a similar space velocity for all tests [20]. A Gas Hourly Space Velocity (GHSV) used in each reactor was equal to $38,000 \mathrm{~h}^{-1}$. A mass spectrometer was used to determine the feed gas and outlet composition. The reactor pressure drop can also be measured using pressure sensors placed upstream and downstream of the reactors [20].

\section{Catalyst for carbon gasification}

The catalyst to be coated in the wall-flow filter should ensure the in-situ gasification of eventual soot formed in a reducing atmosphere at the working temperature to avoid unacceptable backpressure of the exhaust in the plant. Therefore, to ensure that the gasification occurs at the working temperature (around $700{ }^{\circ} \mathrm{C}$ ), nanostructured catalysts have been synthesized and studied for this specific application [55]. In addition, the work of coating and characterizing the wall-flow monoliths with respect to their performance has been carefully carried out.

\section{Catalyst preparation and characterization}

Li-delafossite based catalysts were prepared via solution combustion synthesis (SCS) method [56,57]. A concentrated aqueous solution of various precursors (metal nitrates and urea or glycine) was placed in an oven at $650{ }^{\circ} \mathrm{C}$ for a few minutes in a crucible, so to ignite the highly exothermic and self-sustaining reactions [58-60]. The catalysts were characterized by XRD and BET analysis $[55,56]$.

\section{Catalytic activity tests}

The activity of the catalysts for soot gasification was analyzed by temperature programmed reaction (TPRe). A reducing atmosphere containing $\mathrm{CO}_{2}$ (10.92\%), $\mathrm{CO}(10.6 \%), \mathrm{H}_{2}(26.83 \%)$, $\mathrm{H}_{2} \mathrm{O}(24.87 \%)$ and $\mathrm{N}_{2}(26.76 \%)$ was sent at a constant flow rate of $120 \mathrm{ml} / \mathrm{min}$ to the reactor. Tests were carried out in a fixedbed micro-reactor (Fig. 2 (top-left)) composed of $5 \mathrm{mg}$ of carbon (Printex U), $45 \mathrm{mg}$ of powdered catalyst and $150 \mathrm{mg}$ of inert silica (to reduce the specific pressure drop and to prevent thermal runaways). The tests were carried out by heating the fixed bed from ambient temperature until $850{ }^{\circ} \mathrm{C}$ using a heating rate of $5^{\circ} \mathrm{C} / \mathrm{min}$. A GHSV of $38,000 \mathrm{~h}^{-1}$ was used. The analysis of the outlet gas was performed via an EMERSON XSTREAM XEGP analyzer. The inlet pipes have been overheated to prevent the water condensation. The gas downstream of the reactor passes through a condenser in which the water is condensed before arriving to the analyzer [55].

\section{ATR structured support}

In this research, innovative homogenous lattices composed of cubic, octet and kelvin cells and the conventional random foam structure were designed for the ATR of biogas $[56,57,61]$. First, the performance of the structural supports for the production of hydrogen from the ATR reaction in a pilot plant was investigated. The results of the experimental part have been compared with those obtained from the numerical part to choose the most robust to be used in the plant [54]. The catalytic structured support with the best performance were then used in the demo testing campaign.

\section{Manufacturing}

SiSiC composite ceramics were produced by Erbicol SA. The process to manufacture SiSiC ceramics is based on the reactive silicon infiltration of a preform containing $\alpha$-SiC and carbon. By performing the infiltration at $1500{ }^{\circ} \mathrm{C}$ in vacuum, carbon and silicon react to $\beta$-SiC, while excess silicon densifies the structure. The supports were performed using the innovative hybrid method combining 3D printing of polymer inks with replication followed by their replica (Fig. 3) [62].

This technique combines two industrially mature processes such as polymer 3D printing and replica allowing high throughput large sizes. The following picture shows the endless possibilities in terms of porous architectures which can be designed and printed (Fig. 4). SiSiC is the material which was selected for the present project, but it is possible to produce porous bodies with other materials such as oxides by replica and sintering. Finally, the supports were pre-oxidized at $1400{ }^{\circ} \mathrm{C}$ in air to form an adhesion layer for the subsequent wash coating phase.

\section{Coating process}

The structures were wash coated with $15 \% \mathrm{Ni}-0.05 \% \mathrm{Rh} /$ $\mathrm{MgAl}_{2} \mathrm{O}_{4}$ by dip-slurry coating technology. First, the SiSiC samples were coated with spinel and then calcined at $800^{\circ} \mathrm{C}$ for a certain time. Then, those were impregnated with nickel nitrate solution and calcinated posteriorly at $550{ }^{\circ} \mathrm{C}$. Last, the structures were impregnated with rhodium solution and again calcined.

For the testing at the pilot plant, structures with dimensions $48 \times 100 \mathrm{~mm}$ ( 2 sample of $50 \mathrm{~mm}$ height) were prepared. And, for the testing campaign in the full processor, due to big dimension of the ATR support $(\varnothing 260 \mathrm{~mm} \times \mathrm{L}$ :

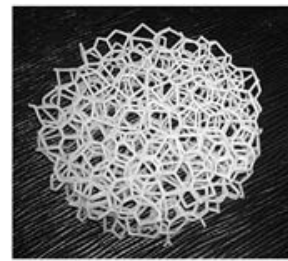

30 printing

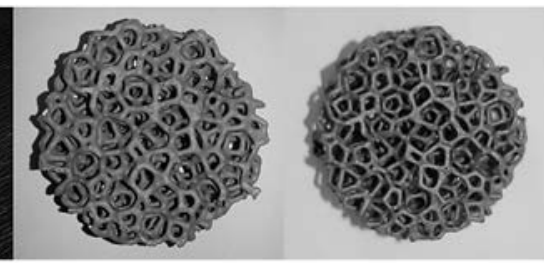

Replica
Silicon infiltration
Fig. 3 - The processing phases of a porous SiSiC body. 

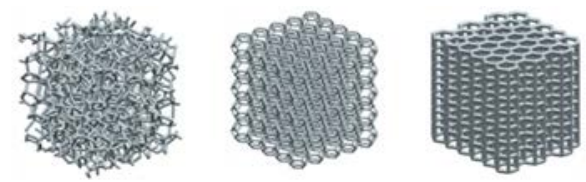

CAD mode

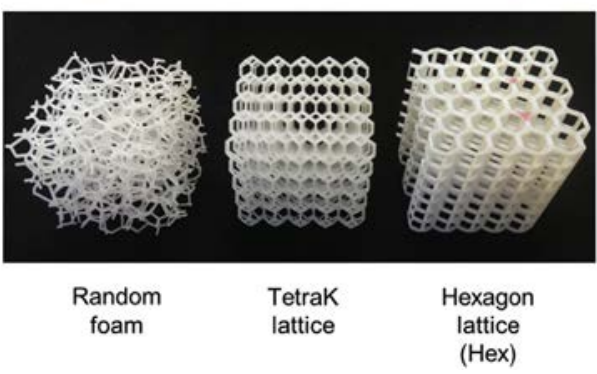

3D printed model

Fig. 4 - Regular and random structures can be designed and printed via this newly developed methodology.

$250 \mathrm{~mm}$ ) and in order to make a complete and uniformed coating, separate flat slices with diameter $260 \mathrm{~mm}$ and thickness $50 \mathrm{~mm}$ were made. The catalyst deposition was verified with SEM analysis.

\section{Wall flow filter}

In view of the additional role of the particle trap as a substrate for catalytic post-treatment of the reformate, the selection of material porosity needs to also account for the pore space needed for the catalytic coatings. In order to select the appropriate filter for the project requirement, a study based on the morphology of soot particles emitted by the reformer was performed. Based on that, filters with 15 and $20 \mu \mathrm{m}$ mean pore size and $46 \%$ porosity were selected. SiC was chosen as the material to be used in this specific application since it is commercially available and it has several advantages, such as high thermal conductivity and mechanical strength. The filters were acquired from the ceramic filter manufacturer (Céramiques Techniques Industrielles S.A) [35].

Carbon gasification catalyst deposition on qualified supports Two different techniques were employed for the coating of the catalysts on the qualified filters. The first coating method is based on in-situ solution combustion (SCD) and the second on aerosol spray pyrolysis (ABD) and direct deposition of the resulting catalyst particles. Both processes employ aqueous solutions of metal nitrate salts. Based on the computational investigation of the different filter substrates described in the first part of this work devoted to modelling and simulation [54], the appropriate substrate was selected depending on the coating process. Coating was conducted at small scale segments (square segments with dimensions $35 \times 35 \times 50 \mathrm{~mm}$ ) for the evaluation at the pilot test-rig scale. In the case of the full-scale filter hat would be introduced downstream of the ATR catalyst in the demonstration plant the dimension were $\varnothing 190 \mathrm{~mm} \times \mathrm{L}$ : $152.4 \mathrm{~mm}$ and the deposition of the carbon gasification catalyst was performed via the aerosol route.

The small monoliths were coated with two different catalyst weights $(5,10$ and $20 \mathrm{~g} / \mathrm{L})$, in order to see the variations in terms of filtration efficiency and pressure drop during loading of carbonaceous. The tests were performed in an engine test bench based on a side stream reactor technology [63], using an engine point with a speed of $1500 \mathrm{rpm}$, a torque of $48 \mathrm{Nm}$ and a brake mean effective pressure of 3.1 bar. All monoliths were loaded under the same conditions. A filtration velocity of $1.1 \mathrm{~cm} / \mathrm{s}$ was used and the loading temperature was kept at $250{ }^{\circ} \mathrm{C}$ to avoid condensation.

The full-scale filter was coated with $20 \mathrm{~g} / \mathrm{L}$ of catalyst. The catalyst deposition was characterized by XRD and FESEM analysis.

Solution combustion and deposition (SCD) method. In the SCD process, $\mathrm{LiFeO}_{2}$ catalyst was deposited by in-situ solution combustion deposition method directly over the wall-flow filters $[55,60]$. The adopted procedure was similar to the one used for the catalyst powder preparation. The precursors (metal nitrates and urea or glycine) were mixed in a beaker with a volume of water and then agitated under a magnetic stirrer.

The ceramic support was dipped in the aqueous solution of its precursors and then placed into an oven at $650{ }^{\circ} \mathrm{C}$. The aqueous phase was rapidly brought to boil, the precursors mixture ignited and the synthesis reaction took place in situ. After total combustion, the filter is cooled down until ambient temperature and then it is weighted. The procedure is repeated enough times until reaching the desired weight of catalyst.

Aerosol based deposition (ABD) method. ABD is a deposition process that is based on the aerosol spray pyrolysis (ASP) technique described in detail in Refs. [52,64,65]. ABD allows the in-situ synthesis and deposition of solid metal oxide particles on porous structures that are placed in the flow path.

\section{Pilot test rig}

Two different pilot test rigs were used to tests the ATR supports. In addition, for the evaluation of the coated filters with respect to their performance during carbonaceous particles loading, an engine test bench was employed, based on a side stream reactor technology [63].

On one side, all the coated structures with a fixed porosity of 0.85 were initially tested in order to individually evaluate their performance. For the evaluation of the catalytic activity, a fixed-bed reactor with a pipe inner diameter of the reactor was $54 \mathrm{~mm}$ (DIN 50) was used. One thermocouple was placed at the entrance of the bed to regulate the inlet temperature, and another thermocouple was placed at the downstream side under the catalyst bed in order to measure the temperature at the outlet of the monolith. The outside shell of the reactor is thermally insulated to reduce heat loss. The catalyst samples were surrounded by fibre quartz paper in order to avoid bypass flow. The catalysts were tested under

Table 1 - Boundary conditions.

\begin{tabular}{ll}
\hline Inlet temperature $\left[{ }^{\circ} \mathrm{C}\right]$ & $500,600,700$ \\
GHSV $\left[\mathrm{h}^{-1}\right]$ & $2000-20,000$ \\
$\mathrm{~S} / \mathrm{C}$ & 2.0 \\
$\mathrm{O} / \mathrm{C}$ & $1.0,1.1,1.2$ \\
\hline
\end{tabular}


the boundary conditions described for each structure in the Table 1.

Eqs. (1)-(3) present the definition of GHSV, S/C ratio, O/C ratio, respectively.

Gas hourly space volume:

GHSV $\left[\mathrm{h}^{-1}\right]=\frac{\dot{\mathrm{V}}}{\mathrm{V}_{\text {Cat }}}=\frac{\text { Volumentic flow rate }\left(\frac{\mathrm{m}^{3}}{\mathrm{~h}}\right)}{\text { Catalyst bed volume }\left(\mathrm{m}^{3}\right)}$

Steam Carbon ratio:

$\frac{\mathrm{S}}{\mathrm{C}}=\frac{\dot{\mathrm{n}}_{\mathrm{H}_{2} \mathrm{O}}}{\dot{\mathrm{n}}_{\mathrm{CH}_{4}}}$

Air Carbon ratio:

$\frac{\mathrm{O}}{\mathrm{C}}=\frac{2 * \dot{\mathrm{n}}_{\mathrm{O}_{2}}}{\dot{\mathrm{n}}_{\mathrm{CH}_{4}}}$

where $\dot{\mathrm{n}}_{\mathrm{H}_{2} \mathrm{O}}$ is moles of steam fed, $\dot{\mathrm{n}}_{\mathrm{CH}_{4}}$ is moles of methane fed and $\dot{\mathrm{n}}_{\mathrm{O}_{2}}$ is moles of oxygen fed to the system.

On the other hand, in order to analyze the interaction of the selected ATR support with the soot trap, a long duration test was performed in the test rig reactor shown in Fig. 2 (middle). The reactor can be divided in four sections starting from the bottom:

a) Feeding section: The gas supply $\left(\mathrm{CH}_{4}, \mathrm{CO}_{2}\right.$, Air and $\left.\mathrm{H}_{2} \mathrm{O}\right)$ is regulated by Mass Flow Controllers. The $\mathrm{CH}_{4}$ and $\mathrm{CO}_{2}$ are mixed together outside the reactor and then fed with the water inside to the water evaporator (external coil where water evaporation takes place). The Air is fed into the mixing section by another smaller coil that preheat the Air. In this way, the presence of explosive mixture before the reactor inlet is minimized.

b) Evaporation and mixing section: the mixing chamber, where $\mathrm{CH}_{4}, \mathrm{CO}_{2}$, Air and $\mathrm{H}_{2} \mathrm{O}$ are mixed together works at $550-600{ }^{\circ} \mathrm{C}$. The working conditions are reached due to the presence of a heat exchanger which maintains the worktemperature of the mixture that feed reactor. The mixed gas temperature and the reactor inlet gas temperature are controlled to ensure the right reaction condition.

c) Reaction section: the catalyst is positioned at the 2/3 upper part of the pipe. In this zone is controlled the exit gas temperature and the inlet gas temperature. In case the temperature decreases, there is a heat exchanger which ensure the constant preheating of the reactor and supply heat for endothermic reactions (i.e. steam reforming).

d) Trap section: the exit gas passes through the soot-trap in order to filter the eventual soot produced in the ATR unit. In this section the temperature before and after the trap, the composition of the gas and the pressure drop across the trap are monitored.

The tests were performed using a GHSV of $10,000 \mathrm{~h}^{-1}$, an S/ $\mathrm{C}$ ratio $=2.0$ and $\mathrm{O} / \mathrm{C}$ ratio $=1.1$ (design values) was used for the experiment section. The catalyst activation in both pilot plants was performed at $750{ }^{\circ} \mathrm{C}$ for $2 \mathrm{~h}$ using a mixture of $25 \%$ $\mathrm{H}_{2}$ and $75 \% \mathrm{~N}_{2}$. Model biogas composed of clean methane and carbon dioxide (60:40 vol:vol) was used in this study.

\section{Demonstration plant}

A compact ATR reactor for the biogas reforming was developed (Fig. 5) for integration in a pure (5.0 grade) hydrogen production at a pre-commercial scale $\left(50 \mathrm{Nm}^{3} / \mathrm{h}\right)$. The major objective is the demonstration of the functionality and the proper interaction of the main components like ATR reactor, steam ejector and soot trap, which together form the innovative plant concept.

The plant is composed of four containers as illustrated in Fig. 5 (left). In the first container (left on the bottom) the water purification and steam generator are integrated. In the upper left container are all components that are related to air such as the air compressor, the dryer and the compressed air tank. In the container on the lower right side are the steam superheater and the physical structure of the ATR unit as best shown in Fig. 5 (right). The ATR inlet is in the upper right container.

The feed section consists in the preheating, compression and mixing of air, steam and biogas streams. The compression of the biogas is provided by a steam ejector, in order to avoid the use of a compressor. The ejector replaces a biogas compressor with the advantages of a simple structure without mobile parts and low costs. Furthermore, it does not require maintenance and it does not have sealing problems. An ejector is commonly defined as a device which converts pressure energy of a motive stream into kinetic energy, entrains a secondary stream, and discharges the mixed stream at an intermediate pressure. The ejector has a double scope. The first one is the mixing of steam, air and biogas whereas the second one is the compression of the biogas.

The feed mixture is preheated in the heater exchanger located at the bottom of the ATR unit (see also Figs. 1 and 2) and then the reagent mixture is fed to the ATR unit. The heart of the process is the ATR-Reactor, in which the biogas is converted in a mixture of gas rich in $\mathrm{H}_{2}$. Close coupled to the ATR unit, there is a wall flow filter to retain the eventual soot produced during the reforming. After the catalyst and soot trap, the synthesis gas produced flows through the gas-gas heat exchanger in which it cools, while the feed gas is heated. The synthetic gas then leaves the ATR unit at the bottom of the vessel. The still hot syngas enters the steam superheater in the middle of the vessel and is cools down as it passes through the heat exchange surface. The cooled synthesis gas exits the heat exchanger in the lower center. The released heat is absorbed by the steam. From the bottom of the vessel the steam passes through the pipes and leaves the steam superheater on the top. Both streams exchange heat following the countercurrent principle. In this way, due to the high temperature gradient, a maximum amount of energy is recovered. And finally, the cooled synthesis gas goes inside the flare.

Alloy $800 \mathrm{H}$ was the material chosen for the piping system. The design was performed according to DIN EN 13480 standard. The ATR unit is made in stainless steel, mineral fiber and ceramic fiber, it has a design temperature of $900{ }^{\circ} \mathrm{C}$ and a design pressure of 1.5. The ATR dimensions are: 

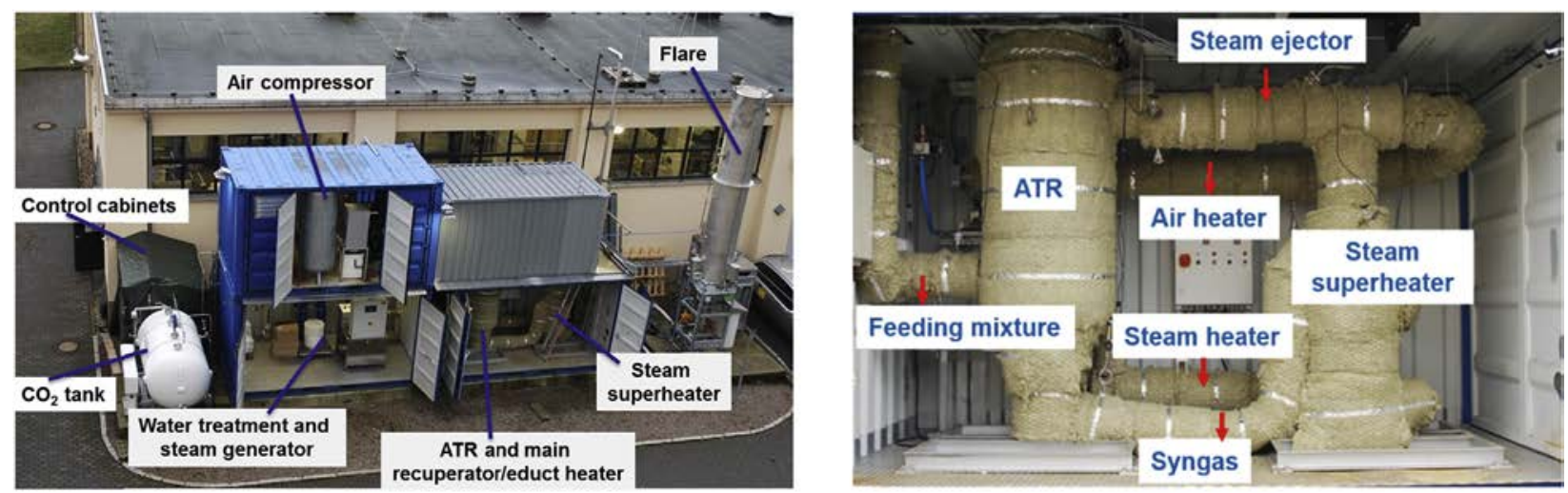

Fig. 5 - Photographs of the realized demonstration plant and components for $\mathrm{H}_{2}$ production. Demonstration plant (left) and ATR container on the lower right side (right).

- Height of complete ATR unit: $2.8 \mathrm{~m}$

- Catalyst diameter: $0.32 \mathrm{~m}$

- Heat exchanger diameter: $0.45 \mathrm{~m}$

A "synthetic biogas" was used rather than real biogas to test the fuel processor, because the demonstration plant is located at a university campus rather than at a biogas site. For producing synthetic biogas, natural gas is used from the urban gas supply network. The natural gas has a concentration of odorant mercaptan of $15 \mathrm{ppm}$ and a concentration of hydrogen sulphide between 0 and $10 \mathrm{ppm}$. To protect the ATR catalyst against poisoning, a mobile desulfurizer was used.

Ten thermocouples were placed along the ATR unit. One was placed at the ATR inlet to measure the inlet temperature, another four were placed above the ATR catalyst, another four were located immediately after the ATR catalyst (i.e. between the ATR catalyst and the soot trap) and the last was located after the soot trap. The synthesis gas production was measured at three different points, at the inlet of the ATR catalyst, after the ATR catalyst (i.e., between the catalyst and the soot trap), and after the soot trap. Gas production was continuously recorded on ABB analyzers.

The plant was controlled from a process control cabinet. The container in which the ATR unit is located was continuously monitored by four cameras.

Two kinds of catalysts were tested in the demonstration plant:

- a noble metal based (mixture of platinum group metals) coated monolith used as a reference. This catalyst was tested close coupled with the uncoated monolith.

Table 2 - Boundary conditions.

\begin{tabular}{lll}
\hline Catalyst structure & Monolith & \multicolumn{1}{c}{ Foam } \\
\hline Material & $\mathrm{Pt} / \mathrm{Rh}$ & $15-0.05 \mathrm{wt} \%$ \\
& & $\mathrm{Ni}-\mathrm{Rh} / \mathrm{MgAl}_{2} \mathrm{O}_{4}$ \\
$\mathrm{O} / \mathrm{C}$ & $0.9-1.3$ & 1.1 \\
$\mathrm{~S} / \mathrm{C}$ & $2.0-15$ & 2.0 \\
$\mathrm{GHSV}\left[\mathrm{h}^{-1}\right]$ & $6000-16,000$ & 4000 \\
$\mathrm{~T}_{\text {in }}\left[{ }^{\circ} \mathrm{C}\right]$ & 450 & 500 \\
Activation & & $25 / 75 \mathrm{H}_{2} / \mathrm{N}_{2}$ \\
& & at $700{ }^{\circ} \mathrm{C}$ for $3 \mathrm{~h}$ \\
Synthetic biogas & $\mathrm{CH}_{4} / \mathrm{CO}_{2}(60 / 40)$ & \\
\hline
\end{tabular}

- a conventional random foam coated with 15-0.05 wt\% Ni$\mathrm{Rh} / \mathrm{MgAl}_{2} \mathrm{O}_{4}$ catalyst. This catalyst was tested together with the coated wall-flow monolith.

Table 2 shows the boundary conditions for the testing campaign for both catalyst structures, monolith and conventional foam.

The foam was activated using a procedure similar to what used for the small-scale samples. First, air was used to heat the catalyst until $300{ }^{\circ} \mathrm{C}$, then, a flow with $25 \% \mathrm{H}_{2}$ and $75 \% \mathrm{~N}_{2}$ was sent to the reactor until reach a temperature equal to $700{ }^{\circ} \mathrm{C}$, afterwards the activation was performed for $3 \mathrm{~h}$ instead of $2 \mathrm{~h}$.

\section{Results and discussion}

\section{ATR catalyst}

Table 3 lists the composition of the catalysts screened for the reforming of biogas. Details on the catalyst characterization can be found in Ref. [20].

The results of catalyst screening in terms of methane conversion and hydrogen production as a function of time on stream are shown in Fig. $6[20,56]$. Most samples show only limited stability over time. The catalyst stability was improved for the samples with higher Ni loadings. The nature of the support also contributed to the catalyst stability. The addition of a small quantity of rhodium had a strong influence on the catalyst stability. 5-0.05 wt\% $\mathrm{Ni}-\mathrm{Rh} / \mathrm{MgAl}_{2} \mathrm{O}_{4}$ catalyst showed full methane conversion over $240 \mathrm{~h}$ with a constant hydrogen

Table 3 - Composition of the tested catalysts.

\begin{tabular}{ll}
\hline Catalyst code & \multicolumn{1}{c}{ Composition } \\
\hline $\mathrm{NM}$ & $5 \mathrm{wt} \% \mathrm{Ni} / \mathrm{MgAl}_{2} \mathrm{O}_{4}$ \\
$\mathrm{NZ}$ & $4.5 \mathrm{wt} \% \mathrm{Ni} / \mathrm{ZnAl}_{2} \mathrm{O}_{4}$ \\
$\mathrm{NL}$ & $4.5 \mathrm{wt} \% \mathrm{Ni} / \mathrm{LaAlO}_{3}$ \\
$\mathrm{NCA}$ & $5 \mathrm{wt} \% \mathrm{Ni} / \mathrm{CeO}_{2}-\mathrm{Al}_{2} \mathrm{O}_{3}$ \\
$\mathrm{NRL}$ & $4-0.05 \mathrm{wt} \% \mathrm{NiRh} / \mathrm{LaAlO}_{3}$ \\
$\mathrm{NRM}$ & $5-0.05 \mathrm{wt} \% \mathrm{NiRh}_{\mathrm{RgAl}} \mathrm{O}_{4}$ \\
$\mathrm{NA}$ & $20 \mathrm{wt} \% \mathrm{Ni} / \mathrm{Al}_{2} \mathrm{O}_{3}$ \\
$\mathrm{NC}$ & $14 \mathrm{wt} \% \mathrm{NiO} / \mathrm{CaAl}{ }_{12} \mathrm{O}_{19}$ \\
\hline
\end{tabular}



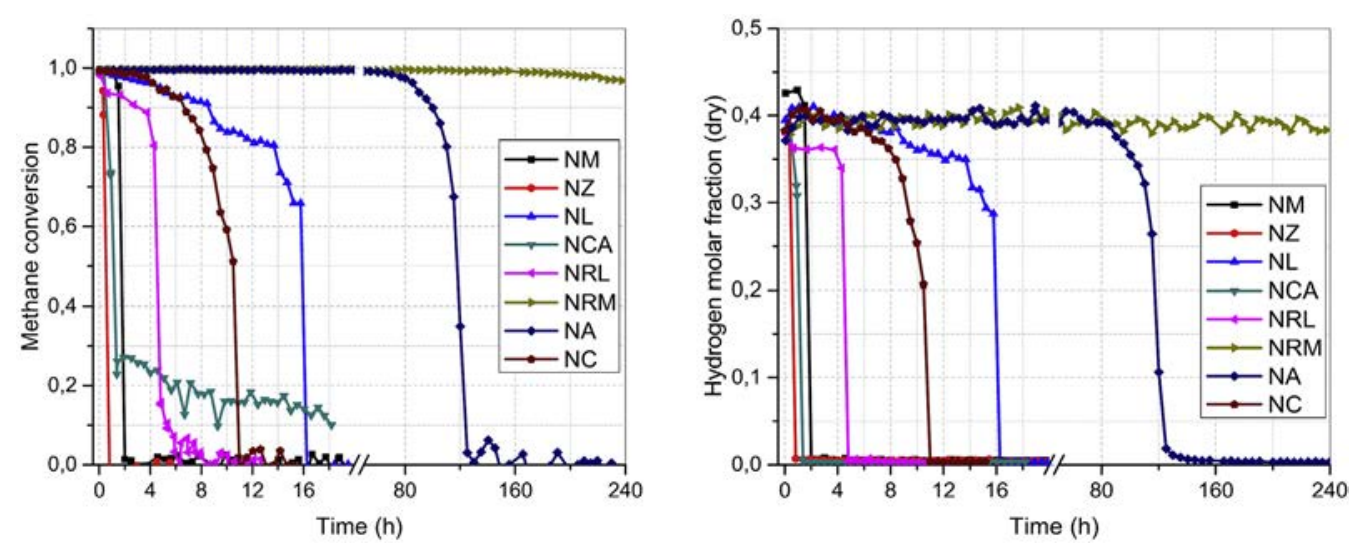

Fig. 6 - Methane conversion (left) and Hydrogen production (right) ( $\mu \mathrm{mol} / \mathrm{min}$ ) from biogas with $60 \%$ of $\mathrm{CH}_{4}$ and $40 \%$ of $\mathrm{CO}_{2}$ at $\mathrm{T}=700{ }^{\circ} \mathrm{C}$ with $\mathrm{S} / \mathrm{C}=3.0, \mathrm{O} / \mathrm{C}=0.5$.

production as showed in Fig. 6 . The good stability of the Rh-Ni catalysts is in line with literature data showing that doping of nickel catalyst with small amounts of noble metals results in better stability, especially under ATR conditions [12].

Very little coke deposition was observed after the test on the catalysts. The main deactivation process was associated to nickel oxidation.

Catalysts with high amount of Ni were tested (Fig. 7) and the most stable nickel based catalyst formulation was $15 \mathrm{wt} \%$ $\mathrm{Ni} / \mathrm{MgAl}_{2} \mathrm{O}_{4}$, which showed full methane conversion over more than $350 \mathrm{~h}$ with a constant hydrogen production of about $0.9 \mathrm{~mol} \mathrm{~kg} \mathrm{cat}{ }^{-1} \mathrm{~s}^{-1}$. Therefore, 5-0.05 wt \% Ni/ $\mathrm{MgAl}_{2} \mathrm{O}_{4}$ was selected as a robust catalyst to be coated on the structured supports.

The behavior of all the synthesized catalyst can be explained with different deactivation phenomena. The deactivation process of the catalyst could be related to some carbon deposition, but the main fast final deactivation process is likely associated to nickel oxidation $[20,27,28,32]$. The latter might be related to the presence of oxygen in the feed stream, leading to nickel oxidation [20]. As mentioned in the

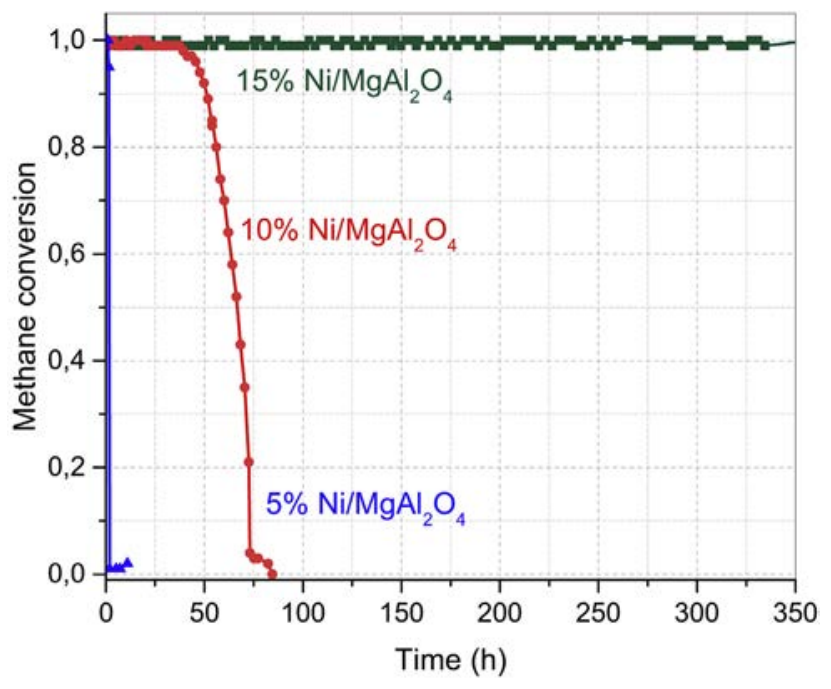

Fig. 7 - Methane conversion from biogas ATR using catalysts with different amount of nickel. introduction, the exothermal combustion occurs at the very inlet of the catalytic bed followed by the reforming process, leads to the formation of hotspots and temperature gradients along the bed [33]. The combination of high temperature and presence of oxygen in the reagent is likely to oxidize the nickel particles, which are no longer involved in the oxidation or reforming reactions. In other words, the deactivation is due to the formation of $\mathrm{NiAl}_{2} \mathrm{O}_{4}$ as is demonstrated by Luneau et al. [33]. When the spinel is formed, no combustion occurs. The exothermal zone progresses along the bed during reaction until complete deactivation.

\section{Catalyst for carbon gasification}

The catalytic activity of the synthesized catalysts was performed in order to select the best formulation to be coated over the wall-flow filter. The complete catalyst screening is shown in Refs. $[55,56]$. The obtained results were very promising, showing relatively fast gasification of soot. $\mathrm{LiFeO}_{2}$, $\mathrm{LiNiO}_{2}$ and $\mathrm{LiCoO}_{2}$ present the best performance to gasification of carbon with $100 \%, 98.5 \%$ and $97.2 \%$ of soot gasified before $850{ }^{\circ} \mathrm{C}$, respectively. While approximately the $39 \%$ is only gasified before $850{ }^{\circ} \mathrm{C}$ when no catalyst in presented during the reaction (Table 4).

Based on this initial screening of potential candidate formulations for the catalytic carbon gasification, $\mathrm{LiFeO}_{2}$ was selected as the catalyst to be further synthesized via the aerosol route as described in a previous paragraph. The synthesis temperature that was employed was $850{ }^{\circ} \mathrm{C}$ in order to be within the temperature window of the operation of the ATR unit.

As it can be observed from the X-ray diffraction spectra (Fig. 8), the synthesized catalysts via solution combustion

Table 4 - Soot conversion in a syngas atmosphere.

\begin{tabular}{lc}
\hline Catalyst & Soot conversion (\%) \\
\hline No catalyst & 39.2 \\
$\mathrm{LiCoO}$ & 97.2 \\
$\mathrm{LiNiO}_{2}$ & 98.5 \\
$\mathrm{LiFeO}_{2}$ & 100 \\
\hline
\end{tabular}



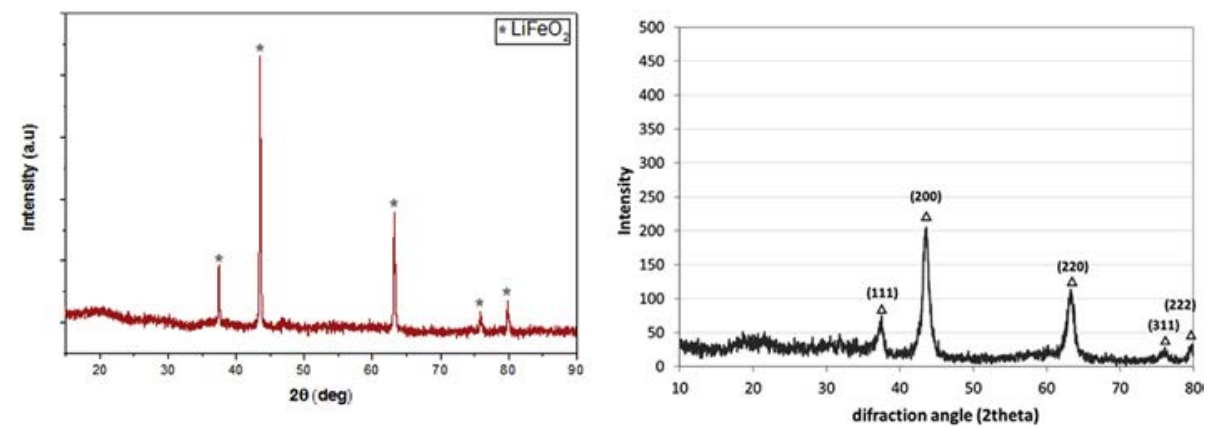

Fig. 8 - X-ray diffraction spectra of the $\mathrm{LiFeO}_{2}$ carbon gasification catalyst synthesized via the aerosol route (left) and solution combustion method (right).

method (Fig. 8 (left)) and aerosol route (Fig. 8 (right)) had the typical phase composition of the specific Li-based formulation.

Square monolithic segments with dimensions $\sim 35 \times 35 \times$ $50 \mathrm{~mm}$ were used for the coating of the $\mathrm{LiFeO}_{2}$ catalyst via the ABD and SCD process. Both methods were applied successfully on the filters to be characterized with respect to their performance during soot particles loading in the engine test bench and to be tested at the pilot test rig [63].

The filter material that was selected for the deposition via ABD was that with the small pore size ( $15 \mu \mathrm{m}$ pore size), since the smaller size of pores would allow the formation of the catalyst layer on the surface of the walls of the monolith which is expected to improve the filtration behavior of the coated filter (e.g. avoid high pressure drop development during filtration of carbon particles on the coated filter) [64]. In the case of the SCD method, filters with 15 and $20 \mu \mathrm{m}$ pore size were coated with 10 and $20 \mathrm{~g} / \mathrm{L}$ of $\mathrm{LiFeO}_{2}$.

As expected the coated filter develops a higher flow resistance compared to the filter with no catalyst deposited on the walls. However, the permeability is only an indication of the initial resistance of the filter to the flow. The performance of the filter during carbon particle deposition is another issue. It has been observed in previous work that during deposition of soot particles on ABD coated monoliths the filters develop lower pressure drop compared to the uncoated filter [64]. This effect is caused mainly because the catalyst particles form a porous layer on the wall of the filter. This layer does not allow the soot to enter inside the wall. The layer of the catalyst operates as a "filter" and the majority of the soot is deposited on that "filter". So, the pressure drop of the ABD coated filter arises only from the resistance that develops from the soot cake, the catalyst layer, the soot inside the catalyst cake and from a small contribution of the filter wall.

When the filter is not coated or when the catalyst is not uniformly deposited (some coating techniques may create non-uniform patches on the surface of the channels) or the catalyst layer is not porous enough so that soot can enter inside the layer, then the total pressure drop is higher. In this case, there is the contribution of the pressure drop developed due to the deposition of soot inside the pores of the filter wall that enhances the resistance to the flow [64-67].

All prepared filters developed low pressure drop during soot particles loading (<10 mbar). In the case of the bigger pore size $(20 \mu \mathrm{m})$ the pressure drop increases in the uncoated filter (Fig. 9 (a)) compared to the coated filters (for the SCD coating technique). This can be attributed to the fact that, in the case of the SCD technique (catalyst loading of 10 and $20 \mathrm{~g} /$ $\mathrm{L})$, the larger pores allow, on one hand, the deposition of a greater amount of catalyst in the pores, but on the other hand, this prevents deposition of soot particles in the pores (which normally takes place in the uncoated filter), therefore reducing the effect of soot loading on the pressure drop. In the case of the $15 \mu \mathrm{m}$ pore size SCD coated filters, increase of the coating amount causes also an increase in the pressure drop during soot loading at levels higher than the uncoated filter. In the case of the ABD filter (with a catalyst loading of $5 \mathrm{~g} / \mathrm{L}$ ) pressure drop was much lower than that of the uncoated filter (Fig. 9 (b)), it being consistent with the results obtained by Lorentzou et al. [64] using aerosol based deposition method.

For the pilot testing campaign, with catalyst coated filters coupled to an ATR pilot unit, appropriate monolithic assemblies were prepared consisting of 4 small scale square monoliths (resulting in a structure with dimensions: $70 \times 70$ $\times 50 \mathrm{~mm}$ ). These filters were either coated after their assembly into the larger structure (case of the SCD route) or they were coated first and assembled at a next step (case of the $\mathrm{ABD}$ route). For the pilot testing campaign, the filters were loaded with $20 \mathrm{~g} / \mathrm{L}$ of catalyst via both coating routes. Both methods were applied successfully on the filter samples and that was demonstrated due that the maximum pressure drop registered was $0.1 \mathrm{psi}$, which means that the coating method did not alter the results of operation of the plant in terms of pressure drop.

In the case of the full-scale filter ( $\varnothing 190 \mathrm{~mm} \times \mathrm{L}: 152.4 \mathrm{~mm})$, that would be introduced downstream of the ATR catalyst in the demonstration plant, as determined by the modelling work, the route that was chosen for the deposition of the carbon gasification catalyst was the aerosol route (ABD). The $A B D$ route was selected for this application due to its advantageous effect during soot particles loading on coated filters, but also for its flexibility in scaling-up from small monolithic segments to full scale filters. Similarly, to the small scale, the microstructure of the filter to be deposited via the aerosol route had the following characteristics: $46 \%$ porosity and $15 \mu \mathrm{m}$ mean pore size. As mentioned before, the carbon 


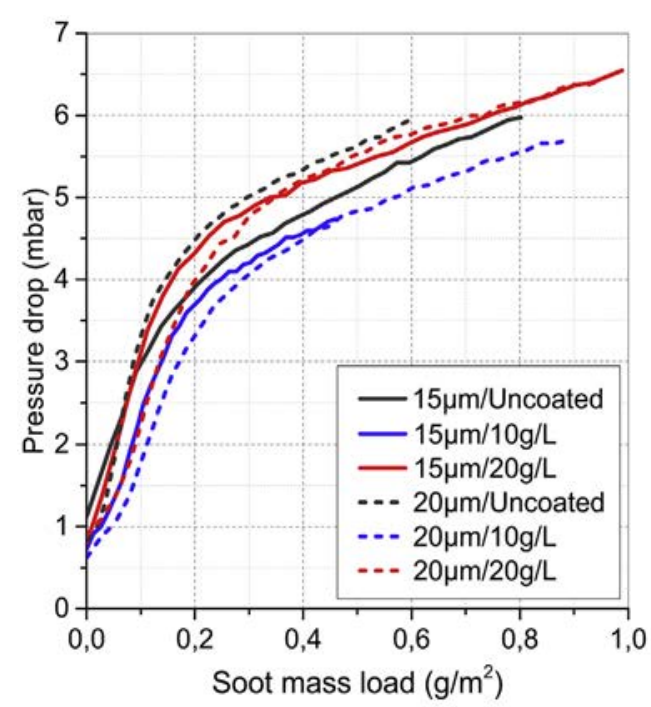

(a)

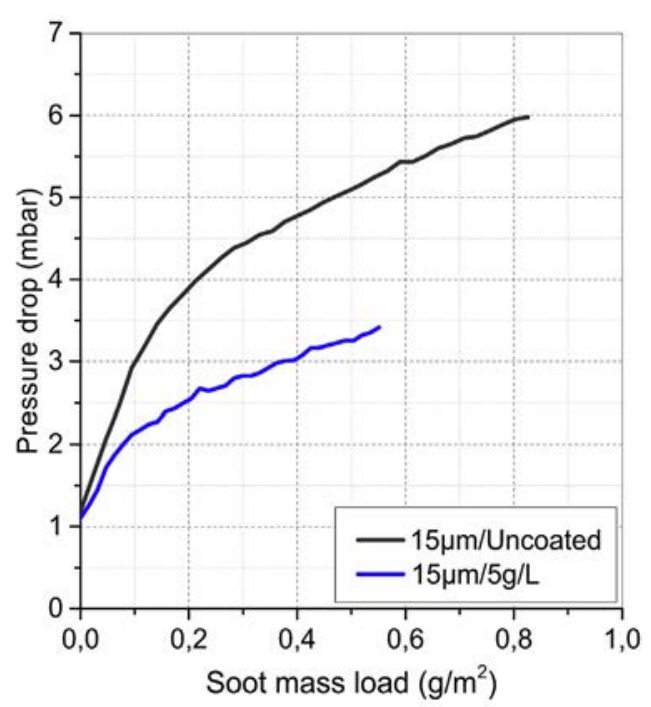

(b)

Fig. 9 - Pressure drop evolution as a function of soot accumulated on the filters for the case of the uncoated and the SCD (a) and ABD (b) catalyst coated filters.

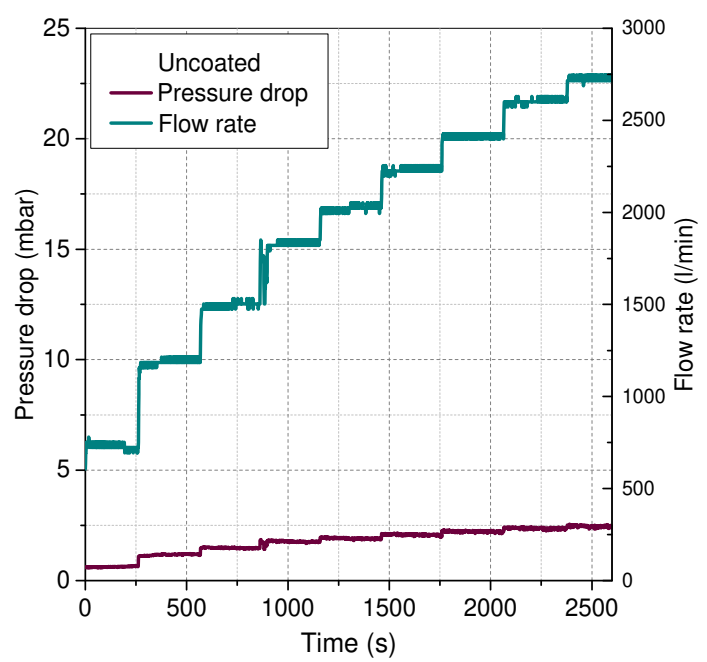

(a)

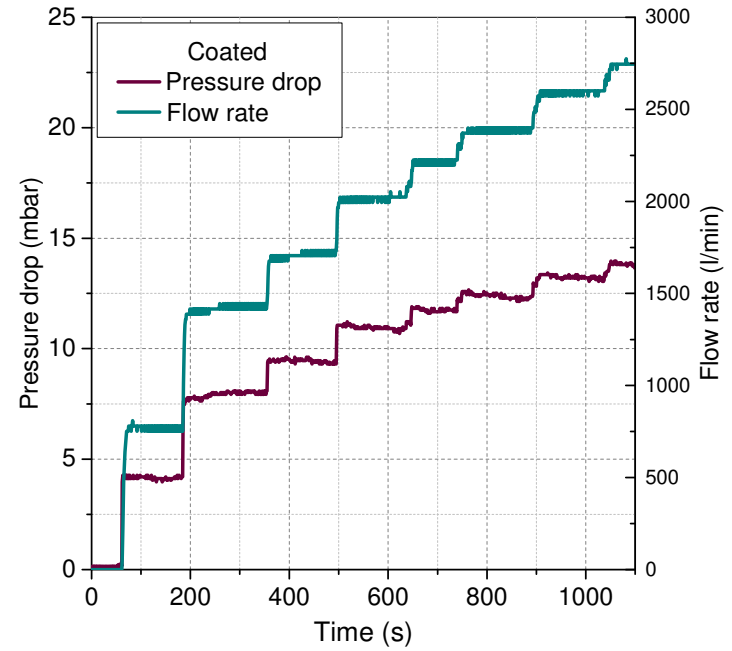

(b)

Fig. 10 - (a) Uncoated full-scale filter, (b) $\mathrm{LiFeO}_{2}$ coated filter via the ABD method.

gasification catalyst that was chosen for the deposition on the monolithic filter was $\mathrm{LiFeO}_{2}$. Air was used as carrier gas for the precursor solution droplets during the coating process and the flow rate was maintained at $400 \mathrm{lpm}$. Catalyst loading was approximately $20 \mathrm{~g} / \mathrm{L}$.

The coated filter was subjected to flow resistance measurement in a dedicated test bench that can deliver adequately high flows (up to approximately $3000 \mathrm{lpm}$ ) for the monitoring of the development of pressure drop in large scale filters. The stepwise increase of the flow from 0 to $2700 \mathrm{lpm}$ and the subsequent pressure drop evolution for an uncoated and $\mathrm{LiFeO}_{2}$ coated filter are presented in Fig. 10. As expected the coated filter develops higher resistance to the flow compared to the uncoated, however it is still maintained at very low values (<15 mbar) at flow rates much higher than what will be employed in the demonstration plant.

\section{Full scale and comparison with the pilot scale}

Several tests were performed with the uncoated soot trap close coupled to the monolith. Results are illustrated in Fig. 11. The system was heating for the start-up and then the heaters were turn off demonstrating the flexibility of the plant. Fig. 10 shows small changes of composition by changing the GHSV from 5,000 to $14,000 \mathrm{~h}^{-1}$. Some fluctuations in composition are present because the outlet temperature (monolith output) varies when the GHSV value changes [7]. Therefore, the inlet temperature fluctuates between the $440-465^{\circ} \mathrm{C}$. Values of $\mathrm{CH}_{4}$ 


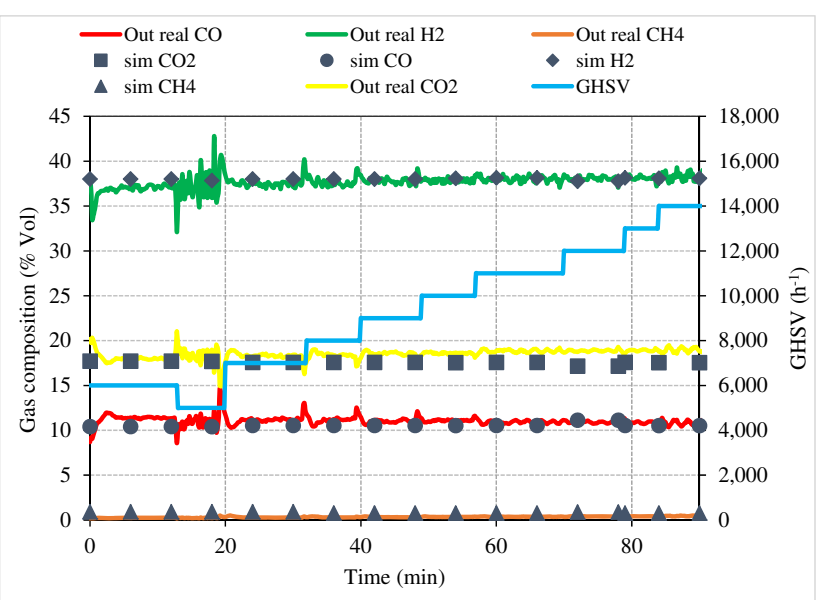

Fig. 11 - Results of the biogas ATR using a monolithcatalyst coupled to the uncoated trap. $O / C=1.1, \mathrm{~S} / \mathrm{C}=2.0$, $\mathrm{T}_{\text {in }}=440-465^{\circ} \mathrm{C}$ with a GHSV from 5000 to $14,000 \mathrm{~h}^{-1}$.

conversion between $98 \%$ and $98.5 \%, \mathrm{H}_{2}$ yield between 1.9 and 2.2 and $\mathrm{H}_{2} / \mathrm{CO}$ ratio between 3.0 and 3.21 were obtained in the range of GHSV (from 5000 to $14,000 \mathrm{~h}^{-1}$ ) used for the biogas reforming test with the monolith.

It was found that $\mathrm{H}_{2}$ yield was higher at lower values of GHSV (low outlet temperature), this could be due to the fact that at high temperatures the reverse WGS reaction (R.2) is favored which produces more $\mathrm{CO}$ when consuming $\mathrm{H}_{2}$. Conversely, $\mathrm{CH}_{4}$ conversion increased with the GHSV, and this could be because the inlet temperature also increases resulting in more combustion products that dilute the syngas.

Simulations were performed in Aspen Plus (performed at affiliation ${ }^{d}$ ) and the results were validated with the experimental part (Fig. 11). The thermodynamic equilibrium was reached during the testing time.

The hydrogen yield and methane conversion were calculated as following (Eq. (4) and Eq. (5)):

$\mathrm{y}_{\mathrm{H}_{2}}=\frac{\dot{\mathrm{n}}_{\mathrm{H}_{2}}}{\dot{\mathrm{n}}_{\mathrm{CH}_{4, \mathrm{in}}}}$

$\mathrm{y}_{\mathrm{CH}_{4}}=\frac{\dot{\mathrm{n}}_{\mathrm{CH}_{4, \text { in }}}-\dot{\mathrm{n}}_{\mathrm{CH}_{4, \text { out }}}}{\dot{\mathrm{n}}_{\mathrm{CH}_{4, \text { in }}}}$

where $\dot{\mathrm{n}}_{\mathrm{H}_{2}}$ is moles of hydrogen produced, $\dot{\mathrm{n}}_{\mathrm{CH}_{4} \text { in }}$ is moles of methane fed to the system and $\dot{\mathrm{n}}_{\mathrm{CH}_{4, \text { out }}}$ is moles of methane out of the system.

The efficiency of the plant was calculated with the following equation:

$\eta_{\text {plant }}=\frac{\dot{\mathrm{m}}_{\mathrm{H}_{2}} \mathrm{LHV}_{\mathrm{H}_{2}}+\dot{\mathrm{m}}_{\mathrm{CO}} \mathrm{LHV}}{\dot{\mathrm{m}}_{\mathrm{CH}_{4}} \mathrm{LHV}_{\mathrm{CH}_{4}}+\mathrm{P}_{\mathrm{i}}}$

where $\dot{\mathrm{m}}_{\mathrm{i}}$ and $\mathrm{LHV}_{\mathrm{i}}$ are the mass flow and the Lower Heating Value of species "i", respectively; $P_{i}$ is the electrical power of component "i" shown in Fig. 1. The Eq. (6) describe the thermal efficiency which is based on considerations of the first law of thermodynamics and is calculated as the energy output divided by the energy input $[8,68]$.

Fig. 12 shows the results of tests with the catalytic 15-0.05\%wt Ni-Rh/ $\mathrm{MgAl}_{2} \mathrm{O}_{4}$ foam coupled with the $\mathrm{LiFeO}_{2}$ - coated filter. The activation procedure was successful and a thermodynamic equilibrium for a biogas reforming using an $\mathrm{O} / \mathrm{C}=1.1, \mathrm{~S} / \mathrm{C}=2.0, \mathrm{~T}_{\text {in }}=500{ }^{\circ} \mathrm{C}$ and $\mathrm{a} \mathrm{GHSV}=4000 \mathrm{~h}^{-1}$ was reached as shown in Figure. The $\mathrm{CH}_{4}$ conversion was equal to $98.9 \%, \mathrm{H}_{2}$ yield equal to 2.1 and $\mathrm{a}_{2} / \mathrm{CO}$ ratio equal to 3.32 .

The plant was able to reach the predicted conversions and concentrations at nominal capacities corresponding to 50 $\mathrm{Nm}^{3} / \mathrm{h}$ (107 Kg/day) of pure hydrogen, creating a negligible pressure drop during the operation time of the processor. The overall behavior fully corresponds to that predicted in the simulation for an ATR of biogas using an O/C ratio of 1.1 and S/ $C$ ratio of 2.0. Furthermore, no pre-reactions were observed before the catalyst nor was soot formation during the testing campaign.

A long duration test (more than $40 \mathrm{~h}$ ) have demonstrated that the processor is reliable and offers a satisfactory reproducibility. Moreover, the results obtained in terms of methane conversion and hydrogen yield showed that the present demonstration plant has better performance compared with other studies founds in literature $[11,48,69,70]$.

For the design condition (GHSV $=10,000, \mathrm{O} / \mathrm{C}=1.1, \mathrm{~S}$ / $\mathrm{C}=2.0$ ) and an inlet temperature of $500{ }^{\circ} \mathrm{C}$ the demo-plant has a plant efficiency of about $65 \%$.

Moreover, this demonstration plant also has generated scale-up engineering data; and credible and verifiable information about future capital and operating expenses (CAPEX and OPEX) were compile [3].

The cold gas efficiency was also calculated as shown in the Eq. (7). Cold gas efficiency is defined as the ratio of the heating value of the product gases to the heating value of the feed gases. In addition to hydrogen, carbon monoxide is also considered because it can be converted in hydrogen due to downstream water gas shift reactors. The cold gas efficiency is used to measure the process performance. The evaluation of cold gas efficiency for several operational conditions identifies the operating ranges to formation of syngas with highest heating value to each fuel.

$\eta_{\text {cold gas }}=\frac{\dot{m}_{\mathrm{H}_{2}} \mathrm{LHV}_{\mathrm{H}_{2}}+\dot{\mathrm{m}}_{\mathrm{CO}} \mathrm{LHV}_{\mathrm{CO}}}{\dot{\mathrm{m}}_{\mathrm{CH}_{4}} \mathrm{LHV}_{\mathrm{CH}_{4}}}$

where $\dot{\mathrm{m}}_{\mathrm{i}}$ and $\mathrm{LHV}_{\mathrm{i}}$ are the mass flow and the Lower Heating Value of species "i", respectively.

The cold gas efficiency is $90 \%$ as predicted with the Aspen simulation for an inlet temperature of $500{ }^{\circ} \mathrm{C}, \mathrm{O} / \mathrm{C}: 1.1$ and S/ C: 2.0 .

The comparison between the results of the pilot scale and those of the complete processor is shown in Fig. 13. Firstly, with respect to the catalytic performance of the catalyst structures, the results obtained in terms of methane conversion and hydrogen yield are excellent compared to the results described in the literature $[38,47,48]$. The results showed that the structured catalyst supports designed within thin study have improved the coupling of the exothermic and endothermic reaction during the biogas ATR [47,69]. Fig. 13 shows the results of the ATR of biogas at the pilot-test rig using $\mathrm{S} / \mathrm{C}=2.0, \mathrm{O} / \mathrm{C}=1.2$ and $\mathrm{T}_{\mathrm{in}}=500{ }^{\circ} \mathrm{C}$ and at the demonstration plant using $\mathrm{S} / \mathrm{C}=2.0, \mathrm{O} / \mathrm{C}=1.1$ and $\mathrm{T}_{\text {in }}=450^{\circ} \mathrm{C}$ and $500{ }^{\circ} \mathrm{C}$, for the monolith and random foam, respectively. 


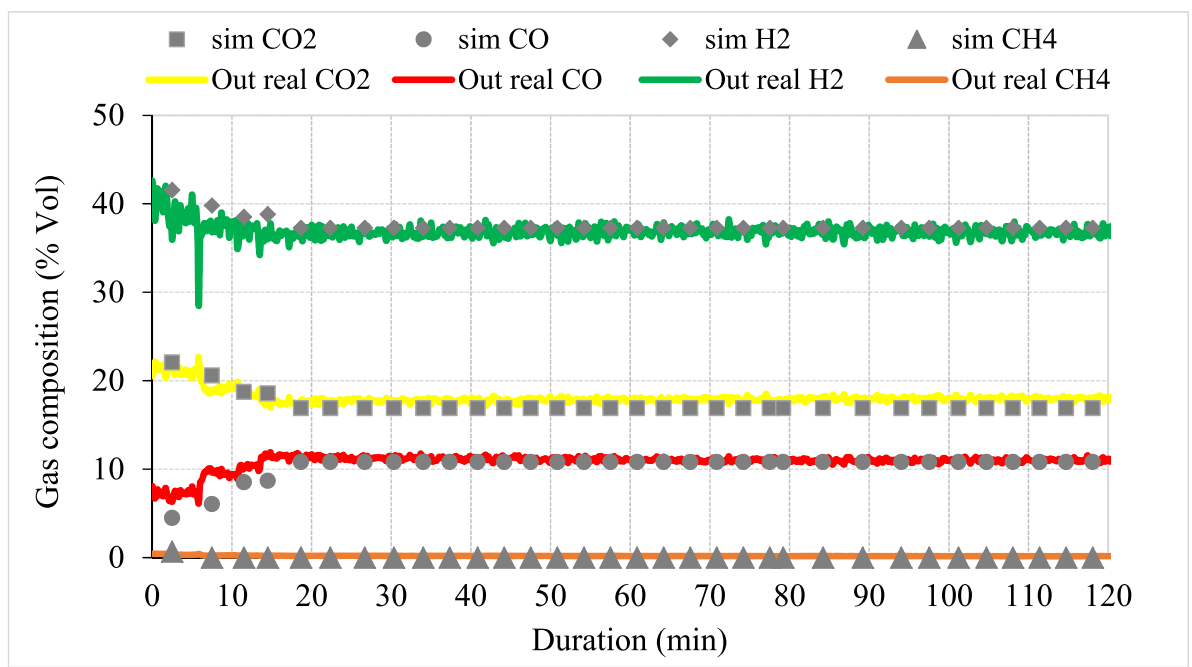

Fig. 12 - Gas Composition (dry) in \%Vol from biogas ATR using a catalyzed foam and coated soot trap using a GHSV = 4000 $\mathrm{h}^{-1}, \mathrm{~S} / \mathrm{C}=2.0, \mathrm{O} / \mathrm{C}=1.1$ and $\mathrm{T}_{\text {in }}=500{ }^{\circ} \mathrm{C}$.
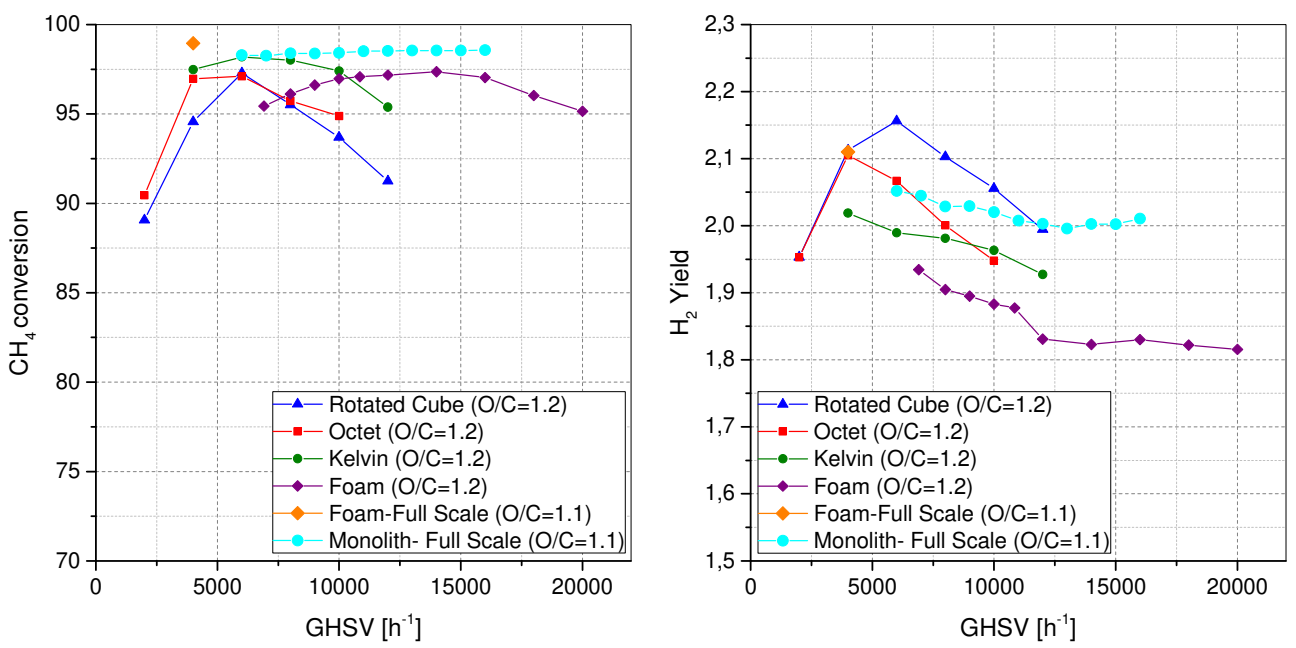

Fig. 13 - Comparison of small-scale $\left(\mathrm{T}_{\text {in }}=500{ }^{\circ} \mathrm{C}\right.$ ) and Demo-plant test results (monolith $450{ }^{\circ} \mathrm{C}$ and foam $500{ }^{\circ} \mathrm{C}$ ). $\mathrm{CH}_{4}$ conversion (left) and $\mathrm{H}_{2}$ (right) yield for an S/C ratio equal to 2.0.

Encouraging experimental results were obtained with the homogenous lattice composed of cubic rotated cell, which presented the best performance to convert biogas into hydrogen with a $\mathrm{CH}_{4}$ conversion higher of $95 \%$ and $\mathrm{H}_{2}$ yield higher of 2.1 in the different boundary conditions in which were tested, O/C of 1.0, 1.1 and 1.2, S/C of 2.0 and GHSV from 2000 to $20,000 \mathrm{~h}^{-1}$. The comparison between the foams, shows that the performance of the demonstration plant is better, because the methane conversion and hydrogen yield are higher. The monolith also showed good performance in terms of methane conversion at different GHSV values. The results from our previous numerical study suggested the lattice structure composed of rotated cube cell as the most suitable catalyst support structure for the biogas ATR. That result has been validated with the experimental data from the pilot plant (Fig. 13) [54].

\section{Conclusion}

A robust and efficient TRL 5 pre-commercial fuel processor was developed and tested, based on the direct ATR of biogas with a nominal hydrogen production rate of $50 \mathrm{Nm}^{3} / \mathrm{h}$.

Innovative structured supports were designed and tested. The $15-0.05$ wt $\% \mathrm{Ni}-\mathrm{Rh} / \mathrm{MgAl}_{2} \mathrm{O}_{4}$ catalyst was found as a robust catalyst for the autothermal reforming of the biogas. A novel catalytic wall-flow trap located downstream from the ATR unit was performed. The coupled system was tested under realistic conditions and it was demonstrated that there was not any alteration of the results of operation of the plant in terms of pressure drop.

The homogenous lattices composed of Cubic, Octet and Kelvin cells and the Conventional Random Foam structures were manufactured by replica of 3D-printed and coated with 
15-.005\%Ni-Rh/ $\mathrm{MgAl}_{2} \mathrm{O}_{4}$ catalyst. The supports were used for the production of hydrogen from the biogas ATR under different operating conditions and the results showed excellent performances in terms of methane conversion and hydrogen yield. Instead, $\mathrm{LiFeO}_{2}$ catalyst formulation was selected as the most prominent candidate for carbon gasification in a reducing atmosphere. The catalyst was in-situ deposited directly over the wall-flow filters. Besides, due to the excellent performance with respect to filtration efficiency and pressure drop development during soot particles loading, a monolith with $15 \mu \mathrm{m}$ mean pore size and $45 \%$ porosity was selected to be tested in the full ATR processor.

Reference tests were performed in the demonstration plant using a noble metal based coated monolith close coupled with an uncoated filter. Moreover, tests with the integration of the catalyzed conventional foam and the catalytic trap were performed. The activation procedure was successful and a long duration test was carried out using a space velocity of $4000, \mathrm{~S} /$ $\mathrm{C}=2.0, \mathrm{O} / \mathrm{C}=1.1$ and $\mathrm{T}_{\text {in }}=500{ }^{\circ} \mathrm{C}$. A thermodynamic equilibrium and a methane conversion higher than $98 \%$ were achieved. The plant was able to reach the predicted conversions and concentrations at nominal capacities corresponding to $50 \mathrm{Nm}^{3} / \mathrm{h}(100 \mathrm{Kg} /$ day $)$ of pure hydrogen, creating a negligible pressure drop during the operation time of the processor. Further, for the design condition (GHSV $=10,000, \mathrm{O} / \mathrm{C}=1.1, \mathrm{~S} /$ $\mathrm{C}=2.0$ ) and an inlet temperature of $500{ }^{\circ} \mathrm{C}$ the demo-plant has a plant efficiency of about $65 \%$. The comparison between the pilot-plant and the demonstration plant showed that better performances were obtained in the demo processor. To finish, the reliability and operating flexibility of the pre-commercial ATR processor has been demonstrated with a significant plant efficiency.

\section{Acknowledgments}

The authors would like to thank the European commission for the financial support of this work in the Seventh Framework Programme project BioRobur under grant agreement $\mathrm{n}^{\circ}$ 325383 .

\section{R E F E R E N C E S}

[1] Abuşoğlu A, Özahi E, Kutlar Aİ, Demir S. Exergy analyses of green hydrogen production methods from biogas-based electricity and sewage sludge. Int J Hydrogen Energy 2017;42:10986-96. https://doi.org/10.1016/ j.ijhydene.2017.02.144.

[2] Coskun C, Akyuz E, Oktay Z, Dincer I. Energy analysis of hydrogen production using biogas-based electricity. Int J Hydrogen Energy 2011;36:11418-24. https://doi.org/10.1016/ j.ijhydene.2010.12.125.

[3] Montenegro Camacho YS, Bensaid S, Piras G, Antonini M, Fino D. Techno-economic analysis of green hydrogen production from biogas autothermal reforming. Clean Technol Environ Policy 2017:1-11. https://doi.org/10.1007/ s10098-017-1341-1.

[4] Abuşoğlu A, Demir S, Özahi E. Energy and economic analyses of models developed for sustainable hydrogen production from biogas-based electricity and sewage sludge. Int J
Hydrogen Energy 2016;41:13426-35. https://doi.org/10.1016/ j.ijhydene.2016.05.105.

[5] Kalamaras CM, Efstathiou AM. Hydrogen production technologies: current state and future developments. Conf Pap Energy 2013;2013:1-9. https://doi.org/10.1155/2013/690627.

[6] Alves HJ, Bley Junior C, Niklevicz RR, Frigo EP, Frigo MS, Coimbra-Araújo $\mathrm{CH}$. Overview of hydrogen production technologies from biogas and the applications in fuel cells. Int J Hydrogen Energy 2013;38:5215-25. https://doi.org/ 10.1016/j.ijhydene.2013.02.057.

[7] Kohn MP, Castaldi MJ, Farrauto RJ. Auto-thermal and dry reforming of landfill gas over a $\mathrm{Rh} / \mathrm{gAl}_{2} \mathrm{O}_{3}$ monolith catalyst. Appl Catal B Environ 2010;94:125-33. https://doi.org/10.1016/ j.apcatb.2009.10.029.

[8] Hajjaji N, Martinez S, Trably E, Steyer J-P, Helias A. Life cycle assessment of hydrogen production from biogas reforming. Int J Hydrogen Energy 2016;41:6064-75. https://doi.org/ 10.1016/j.ijhydene.2016.03.006.

[9] Hajjaji N, Pons M-N, Houas A, Renaudin V. Exergy analysis: an efficient tool for understanding and improving hydrogen production via the steam methane reforming process. Energy Policy 2012;42:392-9. https://doi.org/10.1016/ j.enpol.2011.12.003.

[10] Lin K-H, Chang H-F, Chang AC-C. Biogas reforming for hydrogen production over mesoporous $\mathrm{Ni}_{2 \mathrm{x}} \mathrm{Ce}_{1-\mathrm{x}} \mathrm{O}_{2}$ catalysts. Int J Hydrogen Energy 2012;37:15696-703. https:// doi.org/10.1016/j.ijhydene.2012.03.130.

[11] Izquierdo U, Barrio VL, Lago N, Requies J, Cambra JF, Güemez MB, et al. Biogas steam and oxidative reforming processes for synthesis gas and hydrogen production in conventional and microreactor reaction systems. Int J Hydrogen Energy 2012;37:13829-42. https://doi.org/10.1016/ j.ijhydene.2012.04.077.

[12] Italiano C, Vita A, Fabiano C, Laganà M, Pino L. Bio-hydrogen production by oxidative steam reforming of biogas over nanocrystalline $\mathrm{Ni} / \mathrm{CeO}_{2}$ catalysts. Int J Hydrogen Energy 2015;40:11823-30. https://doi.org/10.1016/ j.ijhydene.2015.04.146.

[13] Choudhary VR, Mondal KC, Choudhary TV. Partial oxidation of methane to syngas with or without simultaneous steam or $\mathrm{CO}_{2}$ reforming over a high-temperature stable-NiCoMgCeO $\mathrm{X}_{\mathrm{x}}$ supported on zirconia-hafnia catalyst. Appl Catal A Gen 2006;306:45-50. https://doi.org/10.1016/j.apcata.2006.03.032.

[14] Xuan J, Leung MKH, Leung DYC, Ni M. A review of biomassderived fuel processors for fuel cell systems. Renew Sustain Energy Rev 2009;13:1301-13. https://doi.org/10.1016/ j.rser.2008.09.027.

[15] Xuan J, Leung MKH, Leung DYC, Ni M. Integrating chemical kinetics with CFD modeling for autothermal reforming of biogas. Int J Hydrogen Energy 2009;34:9076-86. https:// doi.org/10.1016/j.ijhydene.2009.09.002.

[16] Hamedi MR, Tsolakis A, Lau CS. Biogas upgrading for onboard hydrogen production: reforming process CFD modelling. Int J Hydrogen Energy 2014;39:12532-40. https:// doi.org/10.1016/j.ijhydene.2014.06.017.

[17] Rathod VP, Shete J, Bhale PV. Experimental investigation on biogas reforming to hydrogen rich syngas production using solar energy. Int J Hydrogen Energy 2016;41:132-8. https:// doi.org/10.1016/j.ijhydene.2015.09.158.

[18] Rathod V, Bhale PV. Experimental investigation on biogas reforming for syngas production over an alumina based nickel catalyst. Energy Procedia 2014;54. https://doi.org/ 10.1016/j.egypro.2014.07.267.

[19] Djinović P, Batista J, Pintar A. Efficient catalytic abatement of greenhouse gases: methane reforming with $\mathrm{CO}_{2}$ using a novel and thermally stable $\mathrm{Rh}-\mathrm{CeO}_{2}$ catalyst. Int J Hydrogen Energy 2012;37:2699-707. https://doi.org/10.1016/

j.ijhydene.2011.10.107. 
[20] Luneau M, Schuurman Y, Meunier FC, Mirodatos C, Guilhaume N. High-throughput assessment of catalyst stability during autothermal reforming of model biogas. Catal Sci Technol 2015;5:4390-7. https://doi.org/10.1039/ C5CY00702J.

[21] Li D, Nakagawa Y, Tomishige K. Methane reforming to synthesis gas over $\mathrm{Ni}$ catalysts modified with noble metals. Appl Catal A Gen 2011;408:1-24. https://doi.org/10.1016/ j.apcata.2011.09.018.

[22] Rostrup-Nielsen JR. Syngas in perspective. Catal Today 2002;71:243-7. https://doi.org/10.1016/S0920-5861(01)00454-0.

[23] Galvagno A, Chiodo V, Urbani F, Freni F. Biogas as hydrogen source for fuel cell applications. Int J Hydrogen Energy 2013;38:3913-20. https://doi.org/10.1016/j.ijhydene.2013. 01.083.

[24] Jones G, Jakobsen JG, Shim SS, Kleis J, Andersson MP, Rossmeisl J, et al. First principles calculations and experimental insight into methane steam reforming over transition metal catalysts. J Catal 2008;259:147-60. https:// doi.org/10.1016/j.jcat.2008.08.003.

[25] Zhai X, Ding S, Liu Z, Jin Y, Cheng Y. Catalytic performance of Ni catalysts for steam reforming of methane at high space velocity. Int J Hydrogen Energy 2011;36:482-9. https:// doi.org/10.1016/j.ijhydene.2010.10.053.

[26] Rostrupnielsen J. $\mathrm{CO}_{2}$-Reforming of methane over transition metals. J Catal 1993;144:38-49. https://doi.org/10.1006/ jcat.1993.1312.

[27] Helveg S, Sehested J, Rostrup-Nielsen JR. Whisker carbon in perspective. Catal Today 2011;178:42-6. https://doi.org/ 10.1016/j.cattod.2011.06.023.

[28] Foletto EL, Alves RW, Jahn SL. Preparation of Ni/Pt catalysts supported on spinel $\left(\mathrm{MgAl}_{2} \mathrm{O}_{4}\right)$ for methane reforming. J Power Sources 2006;161:531-4. https://doi.org/10.1016/ j.jpowsour.2006.04.121.

[29] Nurunnabi M, Kado S, Suzuki K, Fujimoto Kichiro, Kunimori K, Tomishige K. Synergistic effect of Pd and Ni on resistance to carbon deposition over NiO-MgO solid solution supported Pd catalysts in oxidative steam reforming of methane under pressurized conditions. Catal Commun 2006;7:488-93. https://doi.org/10.1016/j.catcom.2006.01.006.

[30] Habibi N, Wang Y, Arandiyan H, Rezaei M. Biogas reforming for hydrogen production: a new path to high-performance nickel catalysts supported on magnesium aluminate spinel. ChemCatChem 2016;8:3600-10. https://doi.org/10.1002/ cctc. 201601084.

[31] Habibi N, Wang Y, Arandiyan H, Rezaei M. Effect of substitution by $\mathrm{Ni}$ in $\mathrm{MgAl}_{2} \mathrm{O}_{4}$ spinel for biogas dry reforming. Int J Hydrogen Energy 2017. https://doi.org/10.1016/ j.ijhydene.2017.07.222.

[32] Nurunnabi M, Fujimoto K, Suzuki K, Li B, Kado S, Kunimori K, et al. Promoting effect of noble metals addition on activity and resistance to carbon deposition in oxidative steam reforming of methane over NiO-MgO solid solution. Catal Commun 2006;7. https://doi.org/10.1016/ j.catcom.2005.09.002.

[33] Luneau M, Gianotti E, Meunier FC, Mirodatos C, Puzenat E, Schuurman Y, et al. Deactivation mechanism of Ni supported on $\mathrm{Mg}$-Al spinel during autothermal reforming of model biogas. Appl Catal B Environ 2017;203:289-99. https:// doi.org/10.1016/j.apcatb.2016.10.023.

[34] García-Diéguez M, Pieta IS, Herrera MC, Larrubia MA, Alemany LJ. RhNi nanocatalysts for the $\mathrm{CO}_{2}$ and $\mathrm{CO}_{2}+\mathrm{H}_{2} \mathrm{O}$ reforming of methane. Catal Today 2011;172:136-42. https:// doi.org/10.1016/j.cattod.2011.02.012.

[35] Wu JCS, Chou H-C. Bimetallic Rh-Ni/BN catalyst for methane reforming with $\mathrm{CO}_{2}$. Chem Eng J 2009;148:539-45. https:// doi.org/10.1016/j.cej.2009.01.011.
[36] Conner WC, Falconer JL. Spillover in heterogeneous catalysis. Chem Rev 1995;95:759-88. https://doi.org/10.1021/ cr00035a014.

[37] Li D, Shishido T, Oumi Y, Sano T, Takehira K. Self-activation and self-regenerative activity of trace $\mathrm{Rh}$-doped $\mathrm{Ni} / \mathrm{Mg}(\mathrm{Al}) \mathrm{O}$ catalysts in steam reforming of methane. Appl Catal A Gen 2007;332:98-109. https://doi.org/10.1016/ j.apcata.2007.08.008.

[38] Shang Z, Li S, Li L, Liu G, Liang X. Highly active and stable alumina supported nickel nanoparticle catalysts for dry reforming of methane. Appl Catal B Environ 2017;201:302-9. https://doi.org/10.1016/j.apcatb.2016.08.019.

[39] Habibi N, Arandiyan H, Rezaei M. Mesoporous $\mathrm{MgOAl}_{2} \mathrm{O}_{3}$ nanopowder-supported meso-macroporous nickel catalysts: a new path to high-performance biogas reforming for syngas. RSC Adv 2016;6:29576-85. https://doi.org/10.1039/ C6RA01656A.

[40] Gadalla AM, Bower B. The role of catalyst support on the activity of nickel for reforming methane with $\mathrm{CO}_{2}$. Chem Eng Sci 1988;43:3049-62. https://doi.org/10.1016/0009-2509(88) 80058-7.

[41] Daza CE, Gallego J, Moreno JA, Mondragón F, Moreno S, Molina R. $\mathrm{CO}_{2}$ reforming of methane over $\mathrm{Ni} / \mathrm{Mg} / \mathrm{Al} / \mathrm{Ce}$ mixed oxides. Catal Today 2008;133-135:357-66. https://doi.org/ 10.1016/j.cattod.2007.12.081.

[42] Ruckenstein E, Hu YH. Carbon dioxide reforming of methane over nickel/alkaline earth metal oxide catalysts. Appl Catal A Gen 1995;133:149-61. https://doi.org/10.1016/0926-860X(95) 00201-4.

[43] Liu H, Li S, Zhang S, Chen L, Zhou G, Wang J, et al. Catalytic performance of monolithic foam $\mathrm{Ni} / \mathrm{SiC}$ catalyst in carbon dioxide reforming of methane to synthesis gas. Catal Lett 2008;120:111-5. https://doi.org/10.1007/s10562007-9260-0.

[44] García-Vargas JM, Valverde JL, Díez J, Dorado F, Sánchez P. Catalytic and kinetic analysis of the methane tri-reforming over a Ni-Mg/ $\beta$-SiC catalyst. Int J Hydrogen Energy 2015;40. https://doi.org/10.1016/j.ijhydene.2015.05.032.

[45] García-Vargas JM, Valverde JL, de Lucas-Consuegra A, Gómez-Monedero B, Sánchez P, Dorado F. Precursor influence and catalytic behaviour of $\mathrm{Ni} / \mathrm{CeO}_{2}$ and $\mathrm{Ni} / \mathrm{SiC}$ catalysts for the tri-reforming process. Appl Catal A Gen 2012;431:49-56. https://doi.org/10.1016/j.apcata.2012.04.016.

[46] Li C, Xu H, Hou S, Sun J, Meng F, Ma J, et al. SiC foam monolith catalyst for pressurized adiabatic methane reforming. Appl Energy 2013;107:297-303. https://doi.org/ 10.1016/j.apenergy.2013.02.039.

[47] Wei Q, Yang G, Yoneyama Y, Vitidsant T, Tsubaki N. Designing a novel $\mathrm{Ni}-\mathrm{Al}_{2} \mathrm{O}_{3}-\mathrm{SiC}$ catalyst with a stereo structure for the combined methane conversion process to effectively produce syngas. Catal Today 2016;265:36-44. https://doi.org/10.1016/j.cattod.2015.08.029.

[48] Ricca A, Palma V, Martino M, Meloni E. Innovative catalyst design for methane steam reforming intensification. Fuel 2017;198:175-82. https://doi.org/10.1016/j.fuel.2016.11.006.

[49] Raimondi A, Loukou A, Fino D, Trimis D. Experimental analysis of soot abatement in reducing syngas for high temperature fuel cell feeding. Chem Eng J 2011;176:295-301. https://doi.org/10.1016/j.cej.2011.05.112.

[50] Konstandopoulos AG, Johnson JH. Wall-flow diesel particulate filters-their pressure drop and collection efficiency. 1989. https://doi.org/10.4271/890405.

[51] Fino D, Bensaid S, Piumetti M, Russo N. A review on the catalytic combustion of soot in Diesel particulate filters for automotive applications: from powder catalysts to structured reactors. Appl Catal A Gen 2016;509:75-96. https://doi.org/10.1016/j.apcata.2015.10.016. 
[52] Karadimitra K, Papaioannou E, Konstandopoulos AG. Oxidation of diesel particulate in catalytic filters coated by aerosol spray pyrolysis. J Aerosol Sci 2001;32:233-4.

[53] Raimondi A, Fino D, Saracco G. New concept for soot removal from a syngas mixture. J Power Sources 2009;193:338-41. https://doi.org/10.1016/j.jpowsour.2009.01.036.

[54] Montenegro Camacho YS, Bensaid S, Lorentzou S, Vlachos N, Pantoleontos G, Konstandopoulos A, et al. Development of a robust and efficient biogas processor for hydrogen production. Part 1: modelling and simulation. Int J Hydrogen Energy 2017. https://doi.org/10.1016/j.ijhydene.2017.07.147.

[55] Montenegro Camacho YS, Bensaid S, Lorentzou S, Russo N, Fino D. Structured catalytic reactor for soot abatement in a reducing atmosphere. Fuel Process Technol 2017;167:462-73. https://doi.org/10.1016/j.fuproc.2017.07.031.

[56] Montenegro Camacho YS, Bensaid S, Fino D, Trimis D, Herrmann A, Guilhaume N, et al. Biogas robust processing with combined catalytic reformer and trap: BioRobur Project. WIT Trans Ecol Environ 2015;195:463-74. https://doi.org/ 10.2495/ESUS150391. WIT Press.

[57] Montenegro Camacho YS, Bensaid S, Fino D, Herrmann A, Krause H, Trimis D. Development of a robust and efficient biogas processor for hydrogen production in the framework of the European BioRobur project. Naples, Italy: XXXIX Meeting of the Italian Section of the Combustion Institute; 2016 VII3. https://doi.org/10.4405/39proci2016.VII3.

[58] Fino D, Cauda E, Mescia D, Russo N, Saracco G, Specchia V. $\mathrm{LiCoO}_{2}$ catalyst for diesel particulate abatement. Catal Today 2007;119:257-61. https://doi.org/10.1016/j.cattod.2006.08.029.

[59] Civera A, Pavese M, Saracco G, Specchia V. Combustion synthesis of perovskite-type catalysts for natural gas combustion. Catal Today 2003;83:199-211. https://doi.org/ 10.1016/S0920-5861(03)00220-7.

[60] Fino D, Russo N, Cauda E, Saracco G, Specchia V. La-Li-Cr perovskite catalysts for diesel particulate combustion. Catal Today 2006;114:31-9. https://doi.org/10.1016/ j.cattod.2006.02.007.

[61] Herrmann A, Pönisch M, Werzner E, Laurinat M, Rezaei E, Ortona A, et al. Development of an autothermal biogas processor for hydrogen production. Int Gas Union Res Conf
2014;2:1257-67. ISBN: 978-1-63439-408-6. http://members. igu.org/old/IGU\%20Events/igrc/igrc-2014/papers/tp5-59 herrmann.pdf.

[62] Ortona A, D'Angelo C, Gianella S, Gaia D. Cellular ceramics produced by rapid prototyping and replication. Mater Lett 2012;80:95-8. https://doi.org/10.1016/j.matlet.2012.04.050.

[63] Konstandopoulos AG, Kostoglou M, Skaperdas E, Papaioannou E, Zarvalis D, Kladopoulou E. Fundamental studies of diesel particulate filters: transient loading, regeneration and aging. 2000. p. 683-705. https://doi.org/ 10.4271/2000-01-1016.

[64] Konstandopoulos AG, Lorentzou S, Pagkoura C, Boettcher J. Advanced catalyst coating technology for porous substrates. 2007.

[65] Lorentzou S, Pagkoura C, Zygogianni A, Kastrinaki G, Konstandopoulos AG. Catalytic nano-structured materials for next generation diesel particulate filters. SAE Int J Mater Manuf 2008;1. https://doi.org/10.4271/2008-01-0417. 2008-01-0417.

[66] Karadimitra K, Lorentzou S, Agrafiotis C, Konstandopoulos AG. Catalytic particle synthesis via aerosol spray pyrolysis and in-situ deposition on porous filter materials. PARTEC 2004 Int Congr Part Technol 2004;1:4.

[67] Lorentzou S. Aerosol nanoparticles synthesis and their application on monolithic reactors for catalytic soot oxidation and solar hydrogen production from watersplitting. Aristotle University of Thessaloniky; 2010.

[68] Simpson AP, Lutz AE. Exergy analysis of hydrogen production via steam methane reforming. Int J Hydrogen Energy 2007;32:4811-20. https://doi.org/10.1016/ j.ijhydene.2007.08.025.

[69] Maestri M, Beretta A, Groppi G, Tronconi E, Forzatti P. Comparison among structured and packed-bed reactors for the catalytic partial oxidation of $\mathrm{CH} 4$ at short contact times. Catal Today 2005;105:709-17. https://doi.org/10.1016/ j.cattod.2005.06.045.

[70] Palma V, Ricca A, Ciambelli P. Structured catalysts for methane auto-thermal reforming in a compact thermal integrated reaction system. Appl Therm Eng 2013;61:128-33. https://doi.org/10.1016/j.applthermaleng.2013.03.038. 